\title{
Middle Cambrian slope deposits in northern Victoria Land, Antarctica: Fingerprinting small carbonate platforms domi- nated by grainy carbonates and microbial reefs
}

\author{
${ }^{1}$ Department of Geology, Kangwon National University, 1 Kangwondaehak-gil, Chuncheon, 24341, Republic of Korea \\ ${ }^{2}$ School of Earth and Environmental Sciences, Seoul National University, 1 Gwanak-ro, Gwanak-gu, Seoul, 08826, Republic of Korea; \\ *Corresponding author, E-mail: jusunwoo@snu.ac.kr \\ ${ }^{3}$ Division of Earth Sciences, Korea Polar Research Institute, 26 Songdomirae-ro, Incheon, 21990, Republic of Korea \\ ${ }^{4}$ Polar Science, University of Science \& Technology, 217 Gajeong-ro, Yuseong-gu, Daejeon, 34113, Republic of Korea
}

(Received: June 21, 2020; Revised accepted: November 1, 2020)

https://doi.org/10.18814/epiiugs/2020/020090

Carbonate-bearing slope strata are reported from the upper Miaolingian-lower Furongian Spurs Formation in northern Victoria Land, Antarctica, deposited in a backarc basin during the Ross Orogeny. The Spurs Formation consists mainly of shale interbedded with conglomerate and sandstone. It overlies the middle Miaolingian Glasgow Volcanics and volcaniclastic Molar Formation and is overlain by the lower Furongian sandstone-dominated Eureka Formation. The Spurs conglomerate is composed of randomly-oriented, granule- to boulder-sized, polymictic clasts of shale, sandstone and various limestone. These limestone clasts are variable in texture, such as microbial boundstone composed of calcimicrobe Epiphyton and subordinate microbial crust, oolitic-peloidal packstone to grainstone, and minor lime mudstone to wackestone. These are collectively interpreted as slope deposits, in which limestone clasts may have been derived from missing platform margin carbonate, analogous to Cambrian to Lower Ordovician slope successions elsewhere. On the other hand, the rarity of thinly bedded micritic limestones in the Spurs slope successions is markedly distinctive, and possibly reflects subdued production of lime muds behind the platform edge. It suggests that the vanished carbonate platform may have formed within a narrow shelf margin, dominated by coarse-grained carbonate and microbial reefs. Such style of carbonate platforms would contribute to understand how syn-orogenic carbonates initiated and developed in back-arc basins along the pacific margin of Gondwana (i.e., southern Australia and New Zealand).

\section{Introduction}

Carbonate slope successions, which consist of (hemi-)pelagic and resedimented deposits, connect shallow water carbonate platform and deep basin systems (Playton et al., 2010). These slope deposits consist of lime mud to decametric limestone blocks. They are produced in various ways such as platform margin collapse, mass movement, gravity flow, and suspension settling, forming complex stratal architecture and stratigraphic heterogeneity (Coniglio and Dix, 1992; Flügel, 2010). Although slope facies differ greatly from platform carbonate facies, slope deposits commonly contain a record of shallow platforms in transported sediment and thus reveal a wealth of information regarding carbonate platform sedimentation and the interplay of platform-top to basin environments (Coniglio and Dix, 1992; Playton et al., 2010). For example, for many ancient slope deposits there are no shallower platforms, or they are poorly preserved. This is due to subaerial erosion, tectonic disturbance, dolomitization and metamorphism (Coniglio and Dix, 1992; Flügel, 2010; Playton et al., 2010). Slope deposits are thus crucial for reconstructing a facies anatomy of an obscured carbonate platform and for deciphering their formative controls, including biologic productivity, climate, sea-level, tectonics and oceanographic processes (e.g., Watts and Garrison, 1986; Pillevuit et al., 1997; Drzewiecki and Sim, 2002).

During early Paleozoic global sea-level rise, epicontinental seas and carbonate platforms were abundant around tropical regions of Gondwana, Siberia and Laurentia (Pratt et al., 2012). The majority of the carbonate platforms developed in tectonically stable passive margin and intracratonic basins, interpreted to be governed in part by eustatic sea-level changes (e.g., Kwon et al., 2006; Myrow et al., 2006; Gomez and Astini, 2015). They largely accommodated voluminous lime mud deposits in low energy platform interiors, together with platform margin grainy shoals and microbial reefs (e.g., Pratt and James, 1986; Bova and Read, 1987; Goldhammer et al., 1993; Osleger and Montañez, 
1996; Saltzman, 1999; Kwon et al., 2006) and broadly conform to the standard Wilson model of carbonate platforms (Schlager, 2005). On the other hand, platform carbonate dominated by grainy calcareous sediment has also been reported from coeval successions in foreland basins as well as passive margin (Hender and Dix, 2008; Pratt et al., 2012). Despite the rare documentations on lower Paleozoic platforms style in terms of facies types, many of comparable examples have been reported from younger carbonate platform successions in various geodynamic settings, such as rifting, passive margin, foreland, and back-/fore-arc basins (Bosence, 2005; Wilson and Hall, 2010). In addition, the common style of carbonate platforms, with abundant lime muds, also developed in active margin throughout the Phanerozoic (Soja, 1996; Dorobek, 2008). These imply the possibility that a variety of early Paleozoic carbonate platforms may have formed not only in tectonically stable regions, but also in active margin, and thus a comprehensive understanding of types and developmental histories of various early Paleozoic carbonate platforms are far from complete (cf., Pratt et al., 2012).

The Transantarctic Mountains (TAM) of Antarctica extending from the Weddell Sea to the Ross Sea was formed in tropical regions along the eastern Gondwana margin during early Paleozoic. Lower Paleozoic syn-orogenic sedimentary successions including platform carbonate deposits are well exposed along the TAM (Courjault-Rade et al., 1992; Foster et al., 2005). The successions include the Cambrian Series 2 Shackleton Limestone and Miaolingian (middle Cambrian) Nelson Limestone, located in the central TAM and in the part of the TAM area near Weddell Sea, respectively (Rees et al., 1989; Myrow et al., 2002; Evans et al., 2018). In contrast, platform carbonate is extremely rare in northern Victoria Land, the TAM near Ross Sea, although limestone and sandstone clasts from platform margin and shelf are incorporated into the Miaolingian downslope succession, which was deposited in a back-arc basin (Andrews and Laird, 1976; Federico et al., 2009; Rocchi et al., 2011; Kim et al., 2018).

This study describes carbonate-bearing slope deposits from the upper Miaolingian to lower Furongian Spurs Formation of northern Victoria Land, Antarctica, which allow us to reconstruct vanished carbonate platforms within an active margin, and to discuss types and development of early Paleozoic platforms.

\section{Geologic Setting and Methods}

Northern Victoria Land of Antarctica was located in a juncture of the TAM, southeastern Australia and New Zealand forming the PaleoPacific margin during early Paleozoic (Courjault-Rade et al., 1992; Foster et al., 2005). An accretionary complex formed in northern Vic-
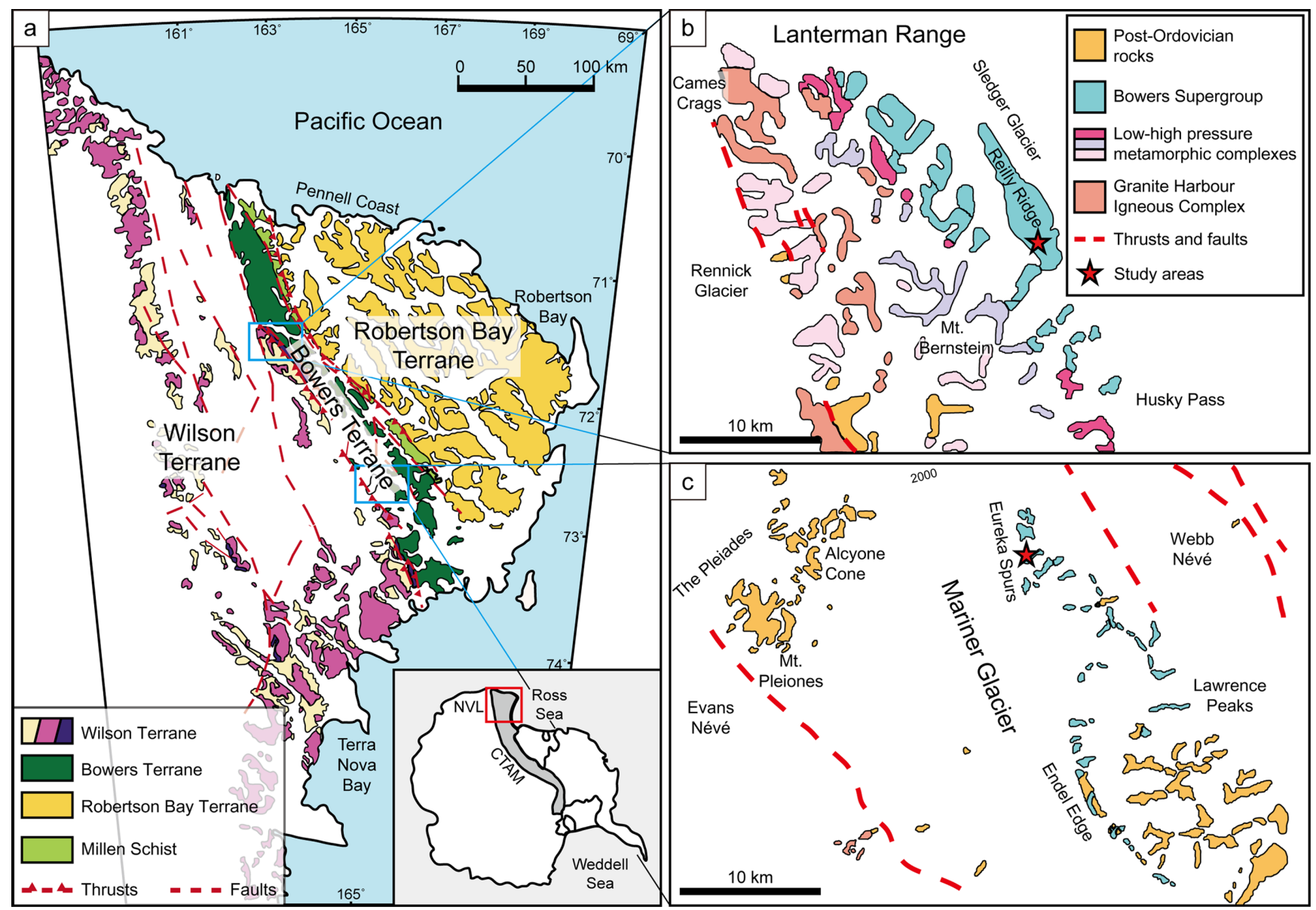

Figure 1. Tectonic elements of northern Victoria Land, Antarctica (a) and geologic maps and study areas in the Lanterman Range (b) and near the Mariner Glacier (c). Modified from Läufer et al. (2011), Capponi et al. (1999) and Di Vincenzo et al. (2001) for figure 1a, b and c, respectively. NVL: northern Victoria Land, CTAM: central Transantarctic Mountains. 
toria Land by attachment of crustal fragments during the early Paleozoic Ross Orogen. It is composed of inboard Wilson, middle Bowers and outboard Robertson Bay terranes (Foster et al., 2005; Federico et al., 2006, 2009; Rocchi et al., 2011; Fig. 1a). The Bowers Terrane covers a narrow strip ca. $370 \times 30 \mathrm{~km}$ and consists of oceanic arc-related sedimentary successions (Capponi et al., 1999). It is bordered westward by the Wilson Terrane of continental arc granitoids and high-grade metasedimentary rocks, and eastward by the Robertson Bay Terrane of flysch deposits (Laird and Bradshaw, 1983; Kleinschmidt and Tessensohn, 1987; Cooper et al., 1990, 1996). Lower Paleozoic rock assemblages in the region are generally considered to be related to westward, oblique subduction processes (Federico et al., 2006; Rocchi et al., 2011).

Lower Paleozoic successions in the Bowers Terrane, named as the Bowers Supergroup, is divided into the middle Miaolingian Sledgers, the upper Miaolingian to lower Furongian Mariner and the upper Furongian to Lower Ordovician Leap Year groups in ascending order (Cooper et al., 1983, 1996; Laird and Bradshaw, 1983). These lithostratigraphic units mainly consist stratigraphically of volcanics and their age-equivalent volcaniclastics (the Glasgow and Molar formations), marine siliciclastic rocks with subordinate carbonate (the Edlin, Spurs, and Eureka formations and the Carryer Conglomerate), and non-marine siliciclastic strata (the Reilly Conglomerate and Camp Ridge Quartzite), respectively. Recent tectonic models illustrate the Sledgers, Mariner and Leap Year groups, which developed during opening and closing of a back-arc basin, and eventual continental collision (Federico et al., 2006, 2009; Rocchi et al., 2011; Rosetti et al., 2011; Paulsen et al., 2016). Initiation and extension of the back-arc basin, contemporaneous with the Sledger Group, is viewed as a result of rollback of a west-dipping subducting plate (Federico et al., 2006, 2009; Rosetti et al., 2011; Paulsen et al., 2016). Subsequent cessation of the basin extension, and turning into a compressional stage are thought to be controlled by continued subduction and continental collision, which are correspond to the occurrence of a regressive succession from the Mariner Group to the Leap Year Group (Federico et al., 2006; Rosetti et al., 2011).

The Spurs Formation, with a maximum thickness of $720 \mathrm{~m}$, is the thickest unit of the Mariner Group and conformably overlies the Edlin Formation and is overlain by the Eureka Formation (Cooper et al., 1983, 1996). The Spurs successions consist largely of shale, with thinly bedded sandstone, carbonate-block-bearing conglomerates and limestone lenses, and are interpreted as downslope and deeper shelf deposits (Laird and Bradshaw, 1983; Kim et al., 2018). Lower and upper boundaries of the formation are somewhat diachronous across the terrane, but they are approximately assigned as late Miaolingian to early Furongian based on trilobite biozones yielded from shale, limestone and carbonate intraclast conglomerate (Cooper et al., 1996; Geyer and Shergold, 2000; Park et al., 2016).

The study localities, approximately $180 \mathrm{~km}$ apart from each other, are in the Reilly Ridge of the Lanterman Range and in the Eureka Spurs bordering east of the Mariner Glacier (Fig. 1a-c). The Reilly Ridge is located in the vicinity of low to high pressure metamorphic complexes formed by accretion of the Wilson and the Bowers terranes (Federico et al., 2009; Fig. 1b). Although the Reilly Ridge is structurally complicated, the Spurs Formation outcrop encompasses numerous relicts of former carbonate platforms that include re-sedimented deposits in the characteristic South End Conglomerate Member and coeval bed- ded carbonate that are weakly metamorphosed (Cooper et al., 1990, 1996; Fig. 2). At the Eureka Spurs, the formation is well-exposed and includes a downslope channel deposit filled with alternating breccia and diamictite with abrupt vertical transition (Andrew and Laird, 1976; Kim et al., 2018; Fig. 3). Kim et al. (2018) interpreted that these breccia and diamictite were deposited from debris flow initiated by allogenic collapse of platform margin and subsequent channel-wall failure. The Spurs Formation was logged in 1:100 scale based on grain types, grain sizes, sedimentary structure, and textures. A total of 108 samples were collected and $2 \times 3$ inches large-format thin sections were made to conduct microfacies analysis, with an emphasis on textural variation of limestone clasts.

\section{Sedimentary Facies}

The Spurs Formation crops out as $295 \mathrm{~m}$ - and 716 m-thick successions in the Fault Slice 3 locality of Reilly Ridge (Cooper et al., 1990, 1996) and the Eureka Spurs 3 locality (Andrew and Laird, 1976; Kim et al., 2018), respectively (Figs. 2, 3). The thinner Reilly Ridge succession is correlated to lower and middle parts of the Spurs succession in the Eureka Spur, which grades upward into the sandstonedominated Eureka Formation (Cooper et al., 1990, 1996; Fig. 3). The Spurs Formation consists of shale (Sh), sandstone (S), conglomerate (C), and packstone to grainstone $(\mathrm{P} / \mathrm{G})$ facies.

\section{Shale Facies (Sh)}

This facies is a few centimeters- to tens of meters-thick, bluish grey homogeneous to faintly laminated shale, which is strongly foliated along the orientation oblique to the bedding (Fig. 4a). It consists largely of claystone with dispersed to layered subordinate quartz silt (Fig. 4b) and some of the shale are calcareous. Shale facies is interbedded with sandstone, conglomerate and packstone to grainstone facies, all of which show sharp bed contacts with one another. Deformed layering of this facies is commonly found in areas stratigraphically or laterally peripheral to other facies and also occur in some horizons overlain and underlain by neighboring shale units that retain primary layers (Figs. 3, 4c).

Homogeneous and laminated shale are interpreted to have been deposited from suspension fall-out of calm-water or low density turbidity current (Markello and Read, 1981; Labaj and Pratt, 2016). Laminae, comprising thick shale, may have been largely deposited from weak flows of Bouma Td and Te turbidity currents (Talling et al., 2012), and those, nearly above the sandstone, might have originated from low density suspended mud at the tail of turbidity currents accumulated by deceleration of the flow (Kneller and Buckee, 2000; Stevenson et al., 2014). Local occurrence of contorted layers implies ductile deformation of temporarily weakened sediment prior to lithification (Maltman and Bolton, 2003; Owen and Moretti, 2011).

\section{Sandstone Facies (S)}

This facies is composed of fine- to coarse-grained sandstone, mainly in centimeters- to decimeters-thick beds and lenses. Amalgamated beds up to $16.5 \mathrm{~m}$ thick are also common. They are sharply bounded below 


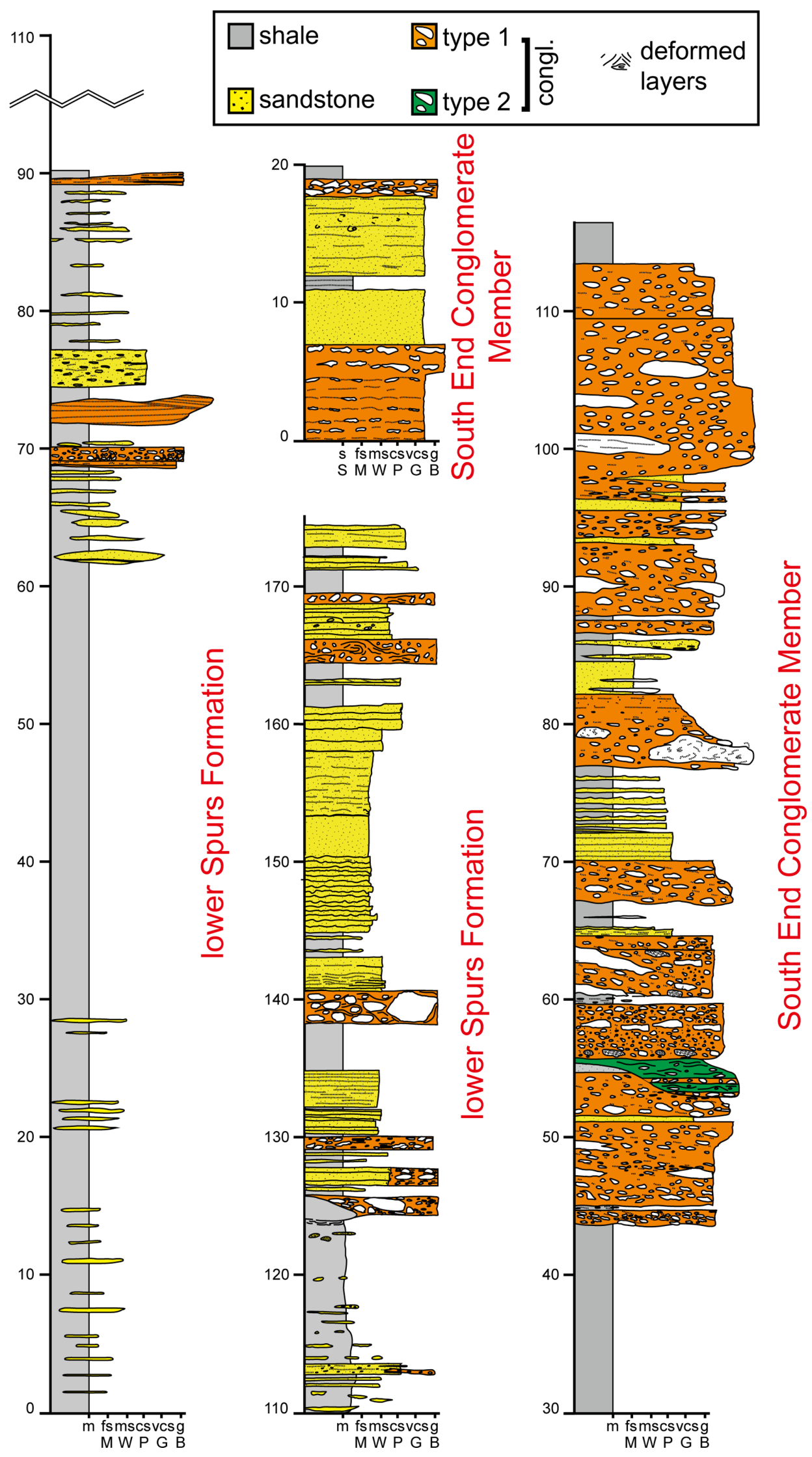

Figure 2. Sedimentary log of the Spurs Formation in Fault Slice 3 (Cooper et al., 1996) of the Reilly Ridge, Lanterman Range showing shaledominated lower Spurs Formation and conglomerate-dominated South End Conglomerate Member containing outsized clasts. m: mud, fs: fine sand, ms: medium sand, cs: coarse sand, vcs: very coarse sand, g: gravel, M: lime mudstone, W: wackestone, P: packstone, G: grainstone, B: boundstone. 

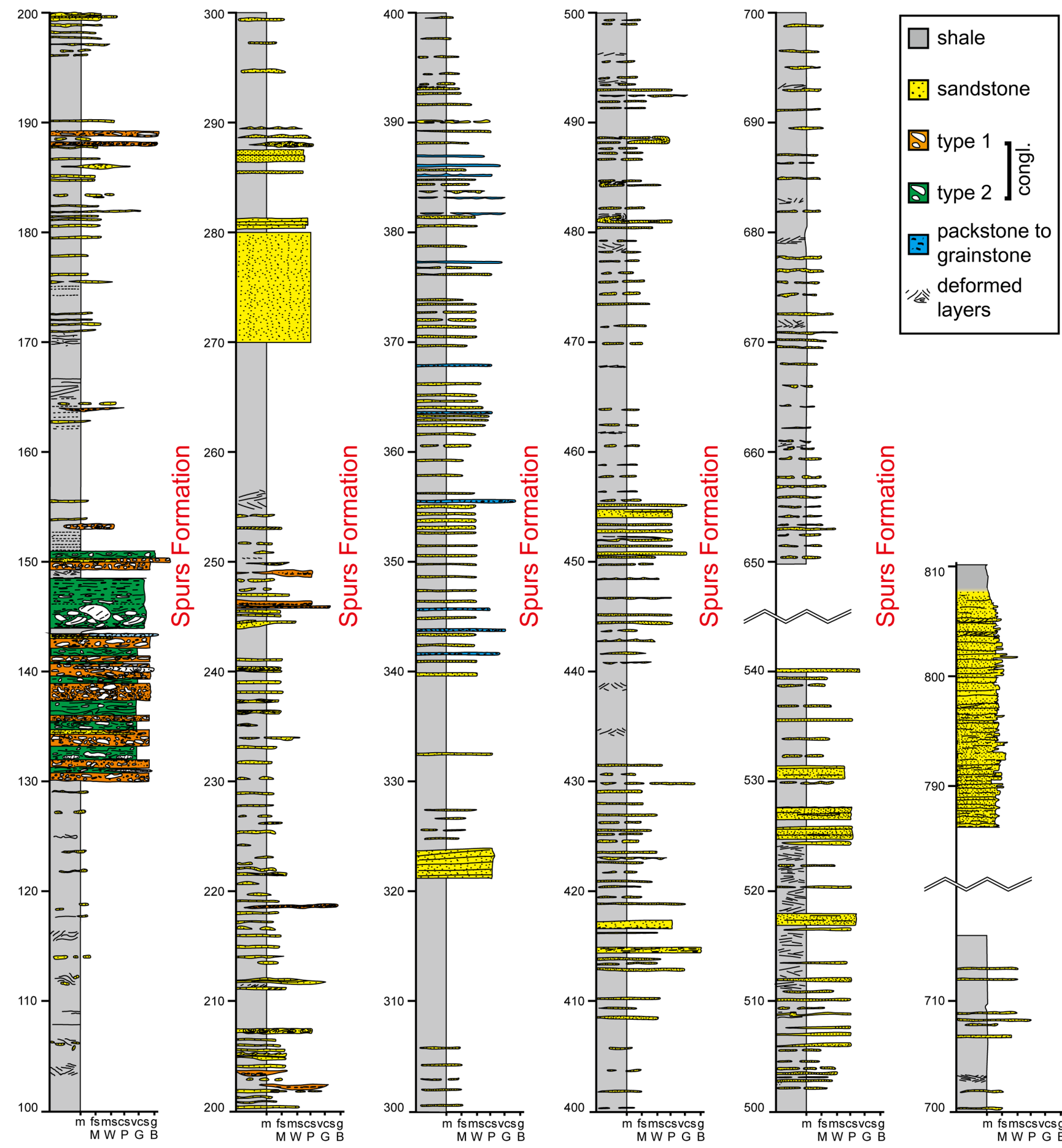

Figure 3. Sedimentary log of the Spurs Formation and lower part of the sandstone-dominated Eureka Formation in the Eureka Spurs near the Mariner Glacier. m: mud, fs: fine sand, ms: medium sand, cs: coarse sand, vcs: very coarse sand, g: gravel, M: lime mudstone, W: wackestone, P: packstone, G: grainstone, B: boundstone.

by basal scours with sole marks, and above by planar or undulatory upper surface (Fig. 4d, e). The sandstone is generally massive, although crude horizontal lamination, cross-stratification and normal grading are locally present (Fig. 4d, e). A few sandstone beds are distorted and tightly folded. This facies consists of moderately sorted, angular to subrounded sands with siliciclastic and calcareous matrix (Fig. 4f). Sand grains are composed mainly of quartz with subordinate plagioclase, biotite and rock fragments of shale, sandstone and volcanics; the sandstone is thus identified as quartz- and lithic-wacke (Fig. 4f). Debris of trilobites and eocrinoids are locally present. This facies is interbedded with shale and conglomerate facies.

Thin beds of fine- to medium-grained sandstone interbedded with shale facies are interpreted to have been transported by turbidity currents (Kneller and Buckee, 2000). Massive to normally graded beds with erosional basal surface are indicative of rapid deposition and subsequent settling during waning of frictional flow (Kim et al., 2018) and planar 

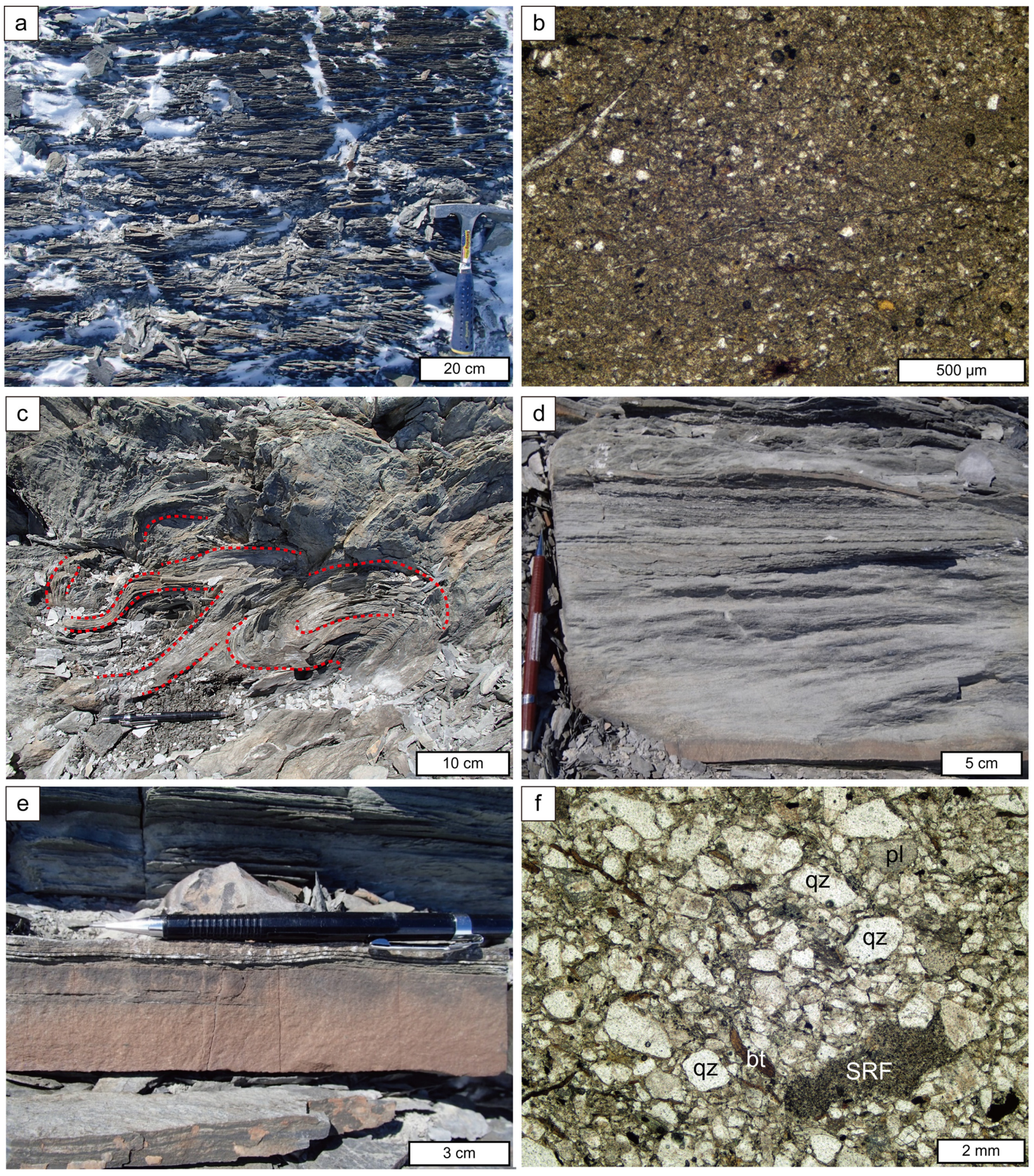

Figure 4. Shale and sandstone facies in the Spurs Formation. (a) Outcrop photograph of shale facies with strong foliations. (b) Plane-polarized photomicrograph of shale facies showing mixed clayey and quartz silty sediment. (c) Outcrop photograph of slumped shale showing folded strata (dashed lines). (d-e) Outcrop photographs of sandstone facies showing medium sandstone beds with cross-and planar stratifications (d) and thin beds of massive to crudely stratified sandstones (e). (f) Photomicrograph of sandstone facies showing subangular to subrounded grains of quartz (qz) and subordinate plagioclase (pl), shaly rock fragment (SRF), and biotite (bt). These poorly sorted sands are enclosed by muddy matrix, indicating sub- to immature nature.

stratification appears to be deposited by tractional processes of relatively low density turbidity currents (Talling et al., 2012). Local contortion of sandstone beds is interpreted as mass movement such as slumping (Arnott, 2010). Composition, rounding and sorting of framework grains, and the existence of matrix, indicate relatively immature to submature nature (Kim et al., 2018).

\section{Conglomerate Facies (C)}

This facies is represented by poorly sorted clasts up to $2 \mathrm{~m}$ in length, comprising a decimeters- to meters-thick single bed and amalgamated units up to $20 \mathrm{~m}$ in thickness (Figs. 2, 3, 5a-d). The majority of this facies is clast- or matrix-supported type 1 conglomerate. They are 

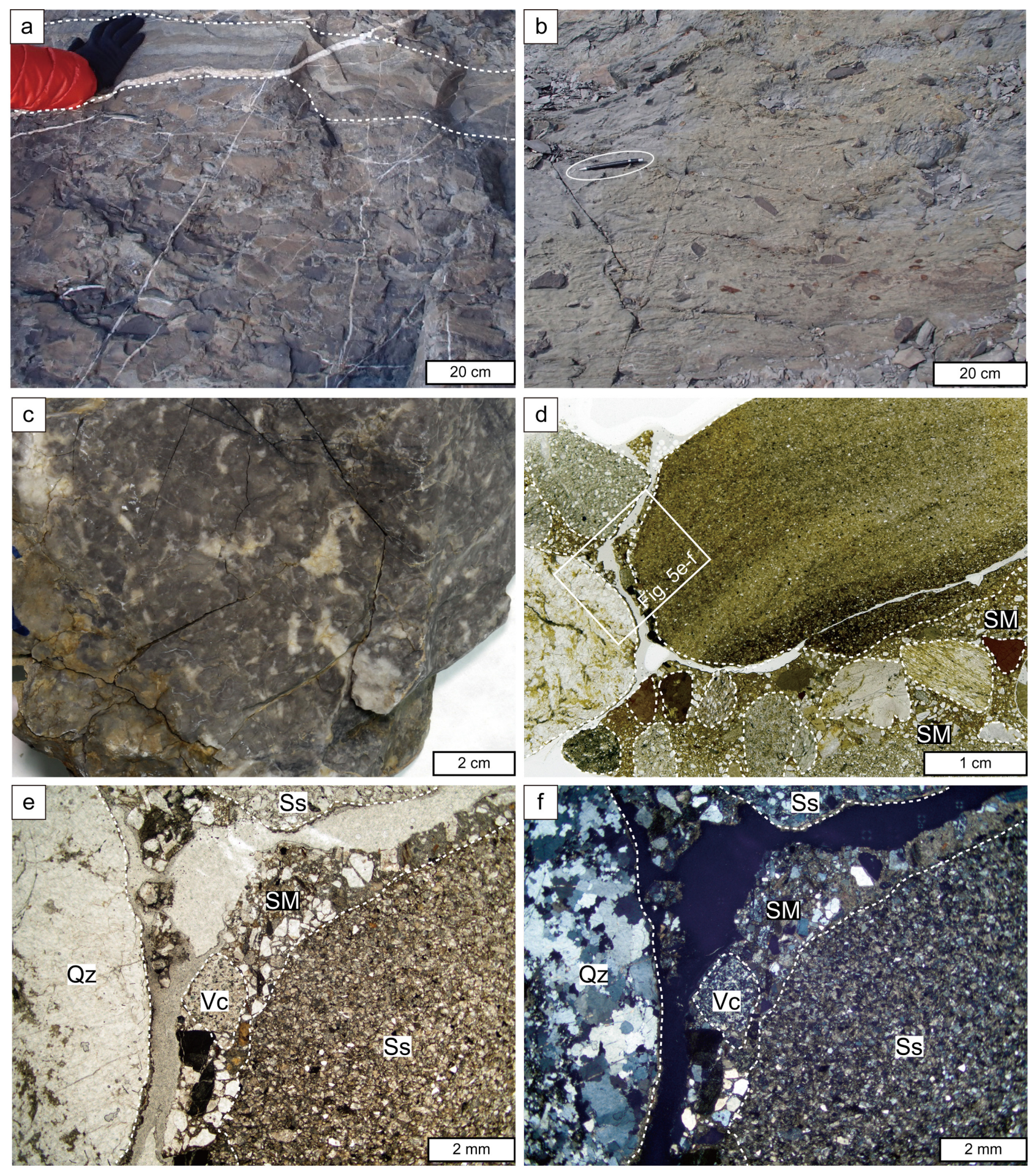

Figure 5. Photographs (a-d) and photomicrographs of conglomerate facies in the Spurs Formation. (a) Poorly sorted and clast-supported type 1 conglomerate and interbedded sandstone (areas within dashed lines). (b) Matrix-supported type 2 conglomerate. (c) A thrombolite clast composed of densely packed darker mesoclots and whitish cement-filled cavities. (d) Polymictic clasts of type 1 conglomerate, enclosed by matrix of wacke sands (SM). (e-f) Enlargement of figure 4d showing that the clasts consist of sandstones (Ss), quartzite (Qz) and volcanics $(V c)$. These photomicrographs are taken under plane- $(e)$ and cross-polarized $(f)$ lights.

composed of angular to rounded clasts, with fine- to medium-grained sandy and oolitic matrices (Figs. 2, 3, 5a). These clasts are mainly disorganized, although some are aligned sub-horizontally. Boundaries of type 1 beds are sharply undulatory, with basal erosional scours. They are generally massive, although crude planar stratification defined by alignment of clasts and inverse grading are locally present. This facies also includes matrix-supported type 2 conglomerate (Figs. 2, 3, 5b), which alternate with the type 1 conglomerate units. The unit boundaries are sharp but erosive features are lacking. They consist of randomly oriented, subrounded to rounded clast that are mainly pebble-grade, 
and relatively homogeneous muddy matrix containing scattered fine sand grains (Fig. $5 b$ ). In the type 2 conglomerate, primary sedimentary structure is hardly recognizable, whereas contorted layers are present in larger clasts and matrix. This facies consists of polymictic clasts that consist of limestone, sandstone and shale; there are a minor component of volcanic and quartzite clasts (Fig. 5c-f). Of them, limestone clasts are well-delineated in outline and particularly variable in internal texture, such as microbial boundstone, packstone to grainstone and lime mudstone to wackestone. Sandstone and shale clasts are similar in composition and sedimentary textures to the siliciclastic facies mentioned above. This facies is most common within intervals incorporating relatively thick, amalgamated sandstone beds.

We interpret the type 1 conglomerate composed of poorly sorted, disorganized clasts up to outsized boulders as cohesionless debris flow deposits (Drzewiecki and Sim, 2002; Talling et al., 2012). In the type 1, presence of rounded clasts that are in cases inversely graded, and the presence of sandy matrix, indicates grain interactions during movement of the particles in traction, creating dispersive stress and the resulting floating of the grains (Mulder and Alexander, 2001; Haughton et al., 2009). Bases of the type 1 conglomerate beds may be nonplanar due to irregular erosion of underlying layers by turbulent flow ahead of debris flow (Sohn et al., 2002). Mud-dominant fabrics and lack of organized clasts in the type 2 conglomerate are suggestive of deposition from cohesive debris flow in which grain interactions were minimal (Mulder and Alexander, 2001).

\section{Packstone to Grainstone Facies (P/G)}

This facies occurs sporadically as laterally continuous thin to medium beds that sometimes pinch out (Fig. 3). They are generally massive, but parallel lamination and cross-lamination are also present. Beds of this facies are sharply overlain and underlain by shale facies beds, and basal scours and normal grading are common. Grains of this facies include peloids, ooids, and trilobite debris, with subsidiary intraclasts, Girvanella-like calcimicrobes, and scattered quartz silt grains (Fig. $6 \mathrm{a}, \mathrm{b})$. Intergranular pores are occluded by calcite cement, with or without geopetal lime mud whose way-up direction conforms to pri- mary upright. Similar to the sandstone facies, thin- to medium bedded calcareous beds are interpreted as turbidite that accumulated rapidly and during waning flow, forming massive and normally graded beds (Pfeil and Read, 1980; Pohler and James, 1989). It cannot be ruled out the possibility that the lenticular grainy deposits with crosslamination can also be interpreted as low-angle bars.

\section{Microfacies of Limestone Clasts in the Conglom- erate Facies}

Limestone clasts consist largely of microbial boundstone, packstone to grainstone and minor lime mudstone to wackestone. Microbial boundstone is thrombolitic, largely composed of densely packed, millimeter- to centimeter-sized amoeboidal mesoclots, platy to arcuate microbial crusts and geopetal infills of which way-up directions do not correspond to the bedding (Fig. 5c). Mesoclots of these thrombolites are composed of poorly to well-preserved calcimicrobe Epiphyton, peloidal lumps, and minor Renalcis-like calcimicrobes (Fig. 7a-e). Epiphyton is characterized by bifurcating micritic filaments 10 $\mu \mathrm{m}$ in diameter (Fig. 7e) whose thalli are oriented upward, sideways, and downward relative to the primary bedding (Fig. 7c, e). Parallel to obliquely aligned microbial crusts a few $\mathrm{mm}$ thick and up to $1 \mathrm{~cm}$ across, irregular peloidal lumps and rare Renalcis-like calcimicrobes with hollow inside co-occur with the Epiphyton thalli (Fig. 7d, e). The interspaces of these microbial elements are filled with micrite containing scattered fine sand- to silt-sized quartz grains and fibrous to blocky calcite cements (Fig. 7a, b). Some growth cavities are lined with scalenohedral calcite cement, as well as subsequent poorly sorted, silt-sized angular calcite crystals, resembling crystal vadose silt (cf., Flügel and Koch, 1995; Fig. 7c). Trilobite fragments and eocrinoid ossicles are rare within the thrombolites.

Packstone to grainstone clasts are composed of variable proportion of peloids, ooids and intraclasts, with subordinate trilobite, eocrinoid fossils, and fine-grained siliciclastic sand and silt (Fig. 8a-d). Spherical to ovoidal ooids and peloids ( $\sim 1 \mathrm{~mm}$ diameter) are generally wellsorted and make up crudely stratified beds (Fig. 8a, d). Clasts are mainly
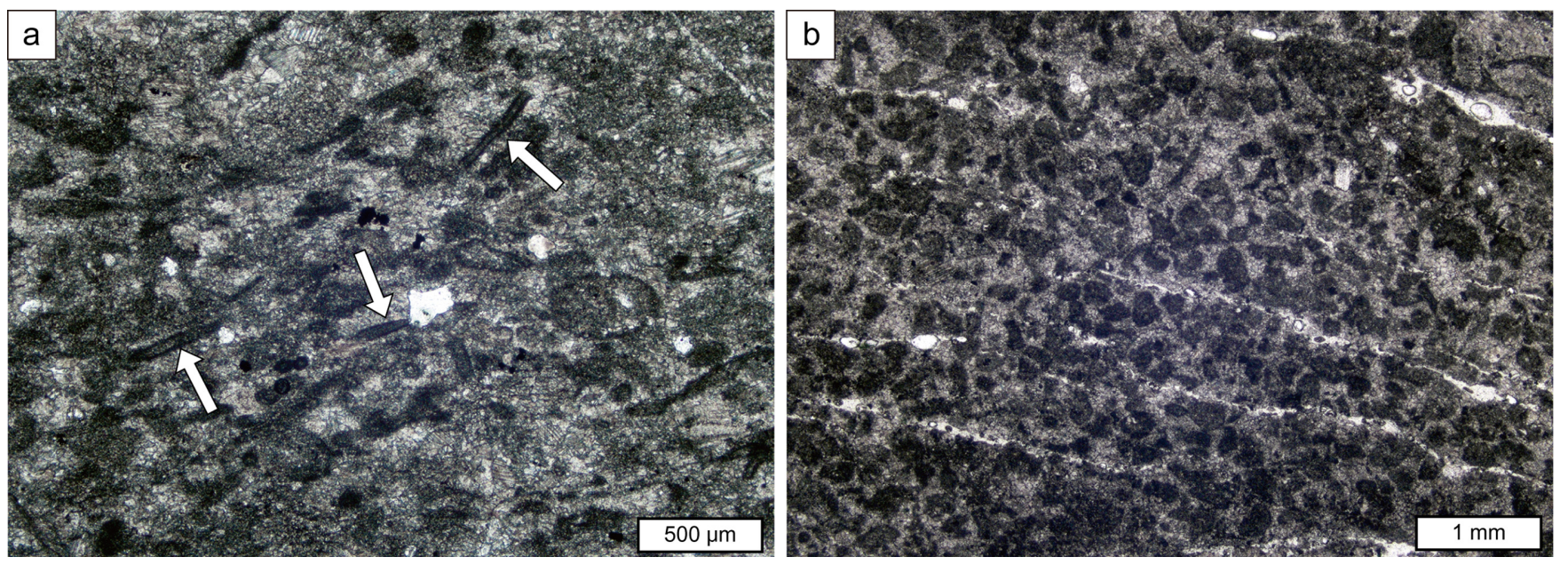

Figure 6. Photomicrographs of packstone to grainstone facies with scattered quartz silts and sands. (a) Poorly sorted packstone to grainstone composed of peloids and Girvanella-like tubular calcimicrobes (arrows). (b) Well-sorted packstone to grainstone dominated by peloids. 

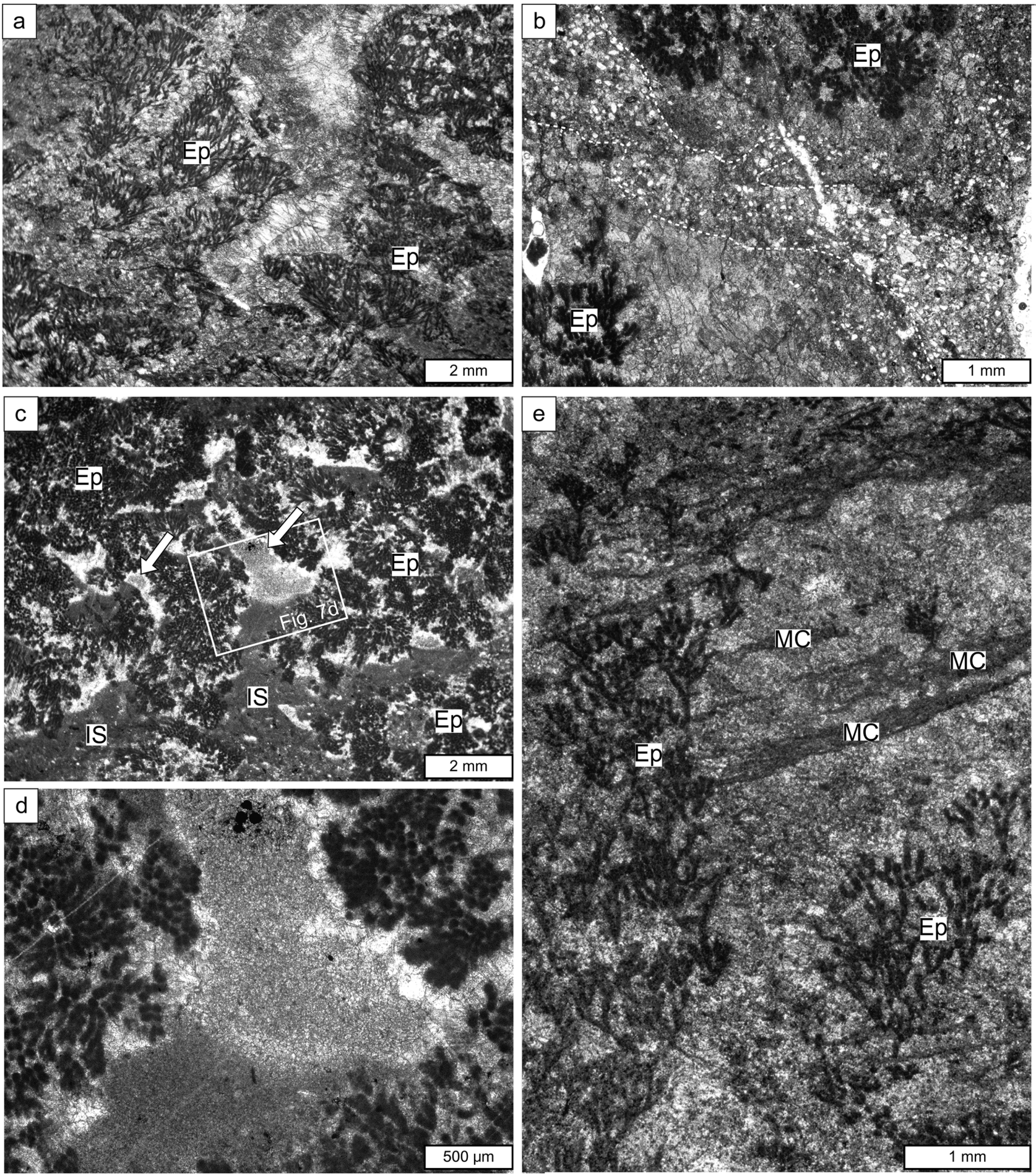

Figure 7. Photomicrographs of boundstone clasts in conglomerate facies. (a) Branching filamentous calcimicrobe Epiphyton (Ep) thalli surrounded by fibrous calcite cement. (b) Upward-growing Epiphyton thalli surrounded by calcite cement and internal sediment with scattered quartz silts. (c) Clustered Epiphyton thalli and their inter-spaces filled with internal micritic sediment (IS), calcite cement and possible crystal silts (arrows). (d) Enlargement of figure 7c showing internal sediment overlain by calcite cement and subsequent crystal silts. (e) Co-occurrence of Epiphyton thalli and platy to arcuate microbial crusts (MC).

composed of subangular to subrounded, centimeter-sized intraclasts (Fig. 8a), variable in fabric such as peloidal-oolitic-intraclastic packstone to grainstone and lime mudstone to wackestone. Intergranular pores within the clasts are commonly filled with micritic matrix and calcite cement with drusy fabric. Lime mudstone to wackestone clasts are rare and largely composed of homogenous lime mudstone (Fig. 8d), with scattered peloids, ooids and quartz silt. Interbedding of intraclastic packstone to grainstone and lime mudstone to wackestone is recorded within a few clasts.

Thrombolites widely occurred in shallow subtidal to deeper sub- 

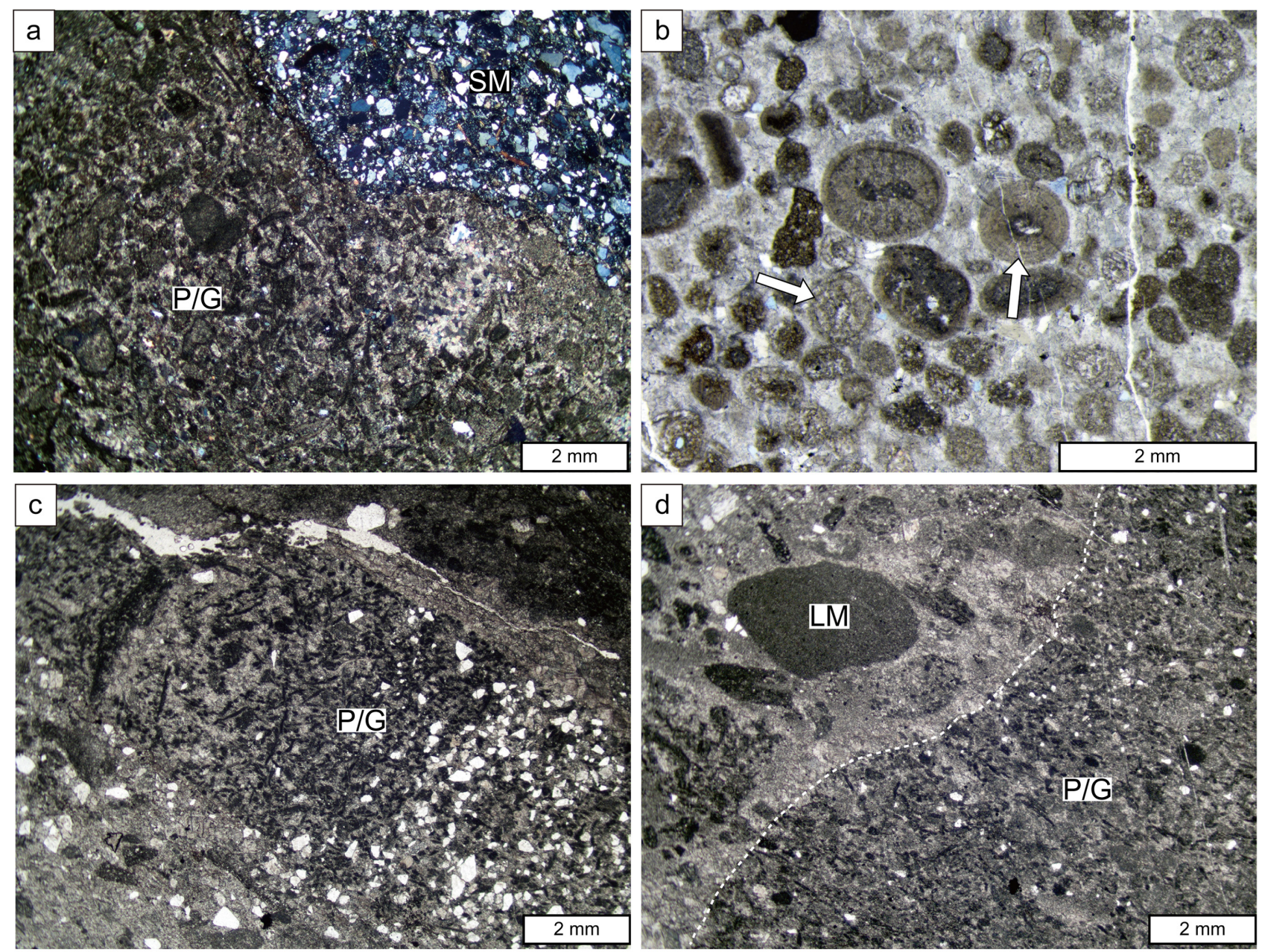

Figure 8. Photomicrographs of packstone to grainstone $(P / G)$ and lime mudstone (LM) clasts in conglomerate facies. (a) Poorly sorted packstone to grainstone clasts in contact with sandy matrix (SM). (b) Grainstone with well- to poorly preserved ooids (arrows) and peloids. (c) Packstone to grainstone clast showing gradual change in relative abundance of quartz grains. (d) Clasts of packstone to grainstone containing scattered quartz silts and homogeneous lime mudstone.

tidal environments during the Cambrian to Early Ordovician and contain preserved calcimicrobes, including Epiphyton and microbial (Girvanella) crusts (Rowland and Shapiro, 2002; Webby, 2002; Lee et al., 2015). Discordant measured way-up directions and incorporation of quartz grains in the Spurs Formation clasts are indicative of derivation from microbial reefs, including thrombolites that developed in a shallower area influenced slightly by siliciclastic influx (e.g., James, 1981; James and Gravestock, 1990; Álvaro et al., 2000). Mesoclots resulted from microbial metabolism and their repeated attachment resulted in the formation of microbial reef frameworks, with the aid of marine cementation (Riding, 2000).

Packstone to grainstone was deposited in moderate to high-energy conditions, and fragments of these grain-rich beds were transported into slope environments (Pohler and James, 1989; Hender and Dix, 2008). Well-sorted peloids and ooids in this microfacies indicate shoal deposition occurring near or above fair-weather wave base (e.g., Youngs, 1978; Srinivasan and Walker, 1993; Sim and Lee, 2006). Intraclastic packstone to grainstone with basal erosive surface and devoid of reefbuilding constituents appears to have been deposited by storm-induced currents containing variable size of calcareous sediment and minor fine siliciclastic sediment (e.g., Markello and Read, 1981; Glumac and Walker,
1997; Gomez and Astini, 2015). Lime mudstone was possibly deposited in lower energy subtidal conditions peripheral to shoals such as back-reef or fore-reef settings (e.g., Rees, 1986; Bova and Read, 1987; Kwon and Chough, 2005).

\section{Reconstruction of the Lost Carbonate Platform: Small Shelf Margin Dominated by Grainy Sed- iment and Microbial Reefs}

The Spurs Formation is dominated by shale with thin tabular to lenticular interbeds of sandstone and conglomerate that contain limestone clasts (Andrews and Laird, 1976; Kim et al., 2018). Common occurrence of gravity flow deposits with slump structures and poorlysorted, megablock-bearing type 1 conglomerate is indicative of downslope transport of clasts from an area of shallower carbonate deposition (Pfeil and Read, 1980; Steiger, 1981; Demicco, 1985). The low level of maturity of the sandstone facies may indicate direct and rapid input of detritus from tectonically active hinterland. Polymictic clasts composed mainly of microbial boundstone and peloidal-oolitic packstone to grainstone are likely to have been sourced from shelf margin 

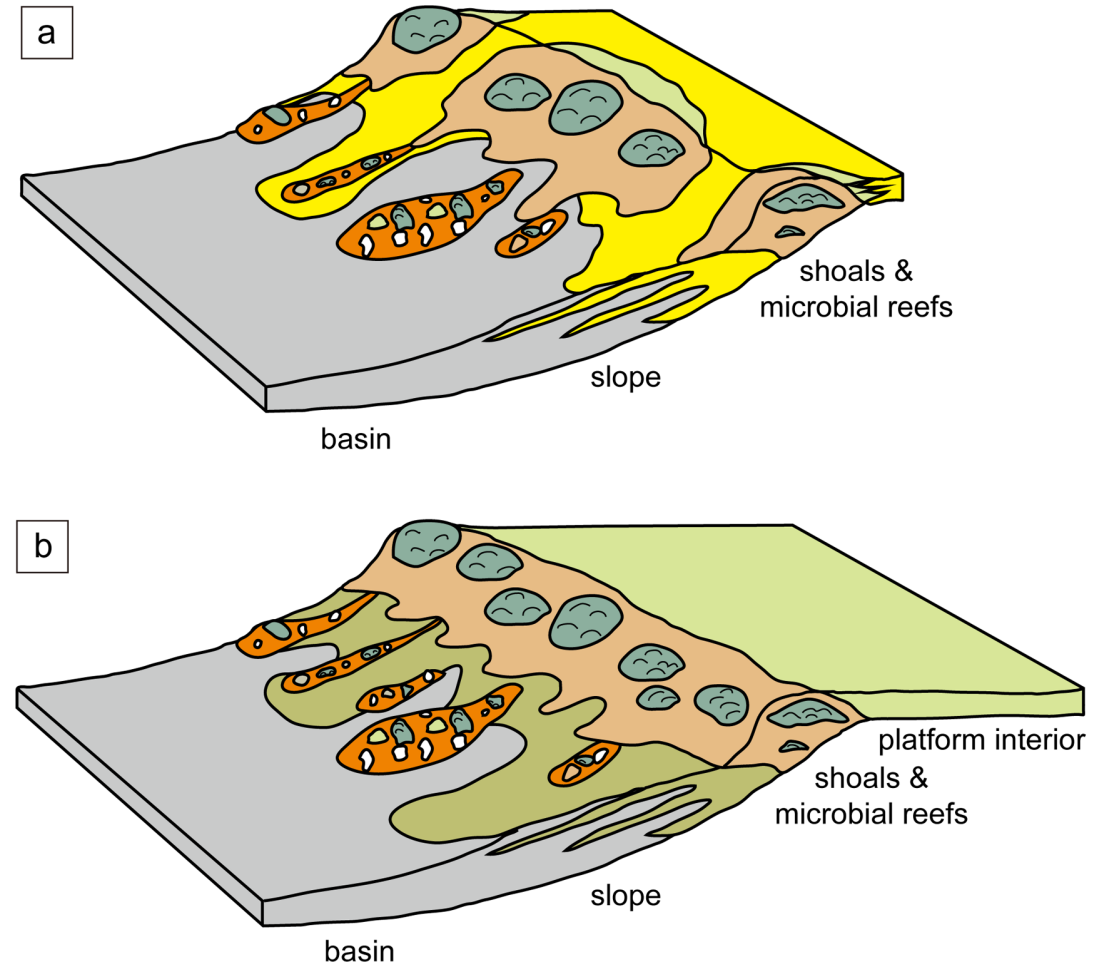
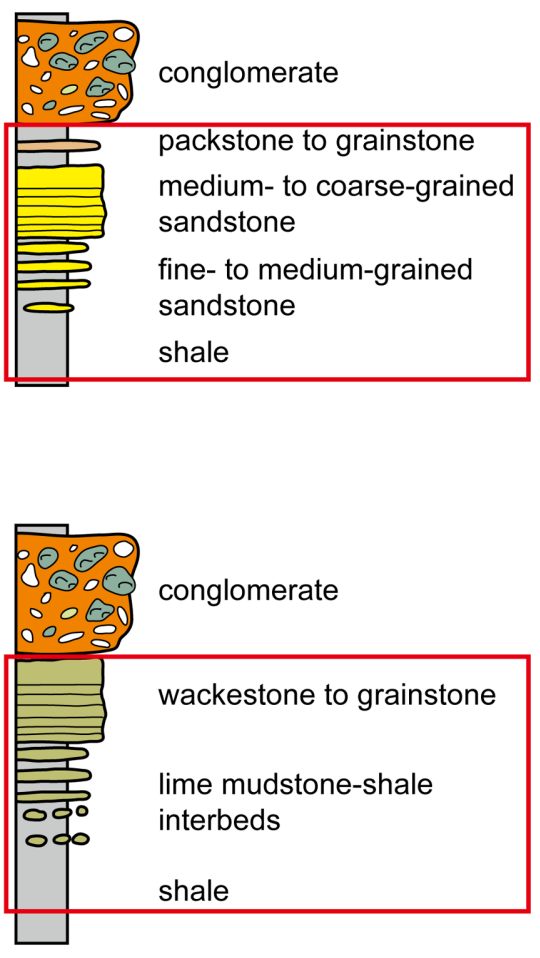

Figure 9. Reconstruction of vanished carbonate platforms on the basis of re-sedimented deposits in Cambrian to Lower Ordovician slope successions whose simplified columnar sections are provided in the right. (a) The Spurs Formation and coeval carbonate platforms dominated by packstone to grainstone shoals and microbial reefs. Note that the small-sized carbonate platforms that developed along the shelf margin and landward shelf rich in sandy sediment, inferred by common occurrence of shale-sandstone interbeds and nearly devoid of micritic limestones in the Spurs Formation (rectangle). (b) Simplified columns of the Miaolingian Shady Dolomite and Lower Ordovician Cow Head Group in eastern North America and their reconstructed carbonate systems. Note the occurrence of thinly bedded and nodular micritic limestone in the slope successions (rectangle), suggesting the presence of lime mud-rich platform interior. Modified from Pfeil and Read (1980) and Pohler and James (1989).

shoals, microbial reefs and adjacent areas associated shallow environments that shed sediment via channels and as broad sheets and flows (e.g., James, 1981; Pohler and James, 1989; Kim et al., 2018). Although the origin and provenance of the sandstone grains are uncertain, they might have originated from the coastal point sources. Whereas there are many coarsening/thickening and fining/thinning upward trends in the Eureka Spurs, eventual coarsening into the sandstone-dominated Eureka Formation reflects an overall regression (Andrews and Laird, 1976).

Similar facies assemblages have been reported from coeval slope and toe-of-slope successions of eastern North America, including shale and poorly sorted breccia with outsized limestone boulders (James, 1981; Pfeil and Read, 1980; Read and Pfeil, 1983; Demicco, 1985; Pohler and James, 1989; Fig. 9). The breccia has been interpreted as mass and debris flow deposits, primarily sourced from platform margin to interior environments (bioclastic-peloidal-oolitic wackestone to packstone and grainstone) and calcimicrobial (Girvanella crust, Renalcis and Epiphyton) reefs. The other carbonate elements in these successions are lime mudstone to wackestone thin beds and nodules interbedded commonly within shale, which were interpreted as hemipelagic settling deposits transported from low-energy platform interior (Demicco, 1985; Pohler and James, 1989; Fig. 9). This interpretation was supported by presence of age-equivalent platform carbonate succes- sions located in the vicinity of the slope successions and viewed as linked carbonate systems (Pfeil and Read, 1980; Demicco, 1985; Pohler and James, 1989).

In the Spurs Formation, there are few lime mudstone and wackestone layers and instead, abundant sandstone beds occur in the succession, which is different from the North American examples described above (Fig. 9). Possible reasons for lack of lime mudstone in the slope succession of the Spurs Formation are ascribed to the non-production of lime mud on the shallow shelf or blocking of transportation of lime mud to deeper environments. If the latter is the case, lime-mud-rich deposits are predicted to occur in the shallower facies. The overlying siliciclastic-dominant succession of the Eureka Formation is suggestive of meager production of lime mud in the shallower shelf. Limited production of lime mud on the shallow shelf can be attributed to physicochemical factors including dissolved oxygen levels, salinity and turbidity (cf., Hender and Dix, 2008; Pratt et al., 2012). These potential factors, abnormal oxygen levels and/or salinity, during deposition of the Spurs Formation, are not supported by any evidence. On the other hand, beds of shelf-derived sandstone and thick shale in the slope succession (Spurs Formation) and thick beds of sand and shale in the shelf succession (Eureka Formation) suggest that an ample influx of siliciclastic sediments could have impeded lime mud production in shallow inner shelf. Some of these may have dissected the areas of 
prolific carbonate and reached the shelf margin (Fig. 9). These collectively suggest that the vanished locus of carbonate factory, which was dominated by grainy calcareous sediment and microbial reefs, defined a narrow and discontinuous geomorphology around the shelf margin (Fig. 9).

\section{Geodynamic Controls on Development and Demise of the Lost Carbonate Platforms}

Recent tectonic models, proposed from northern Victoria Land, depict a broad depositional history of the Bowers Supergroup, which is linked with the geodynamic evolution of the basin (Federico et al., 2006, 2009; Rocchi et al., 2011; Rosetti et al., 2011; Paulsen et al., 2016). A wide range of geochemical affinities of the Sledgers Group volcanics and volcaniclastics, suggests the initial depositional setting to the extending back-arc during the middle Miaolingian (Federico et al., 2006, 2009; Rocchi et al., 2011; Fig. 10). Conglomerate in the Sledgers Group (the Molar Formation) includes rare limestone clasts (Federico et al., 2006, 2009), suggesting the low rate of carbonate production, contemporaneous with volcanic activity. The upper Miaolingian to lower Furongian Mariner Group, which records an overall regression from deep to shallow marine environments, points to the sedimentation during volcanic quiescence and the following compressional stage (Federico

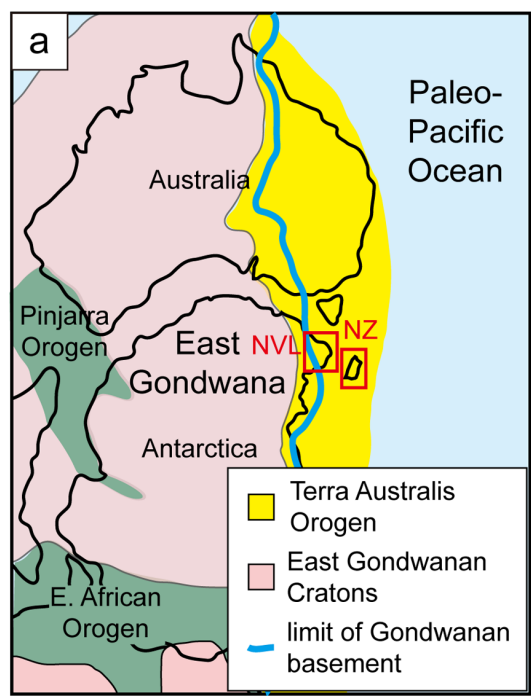

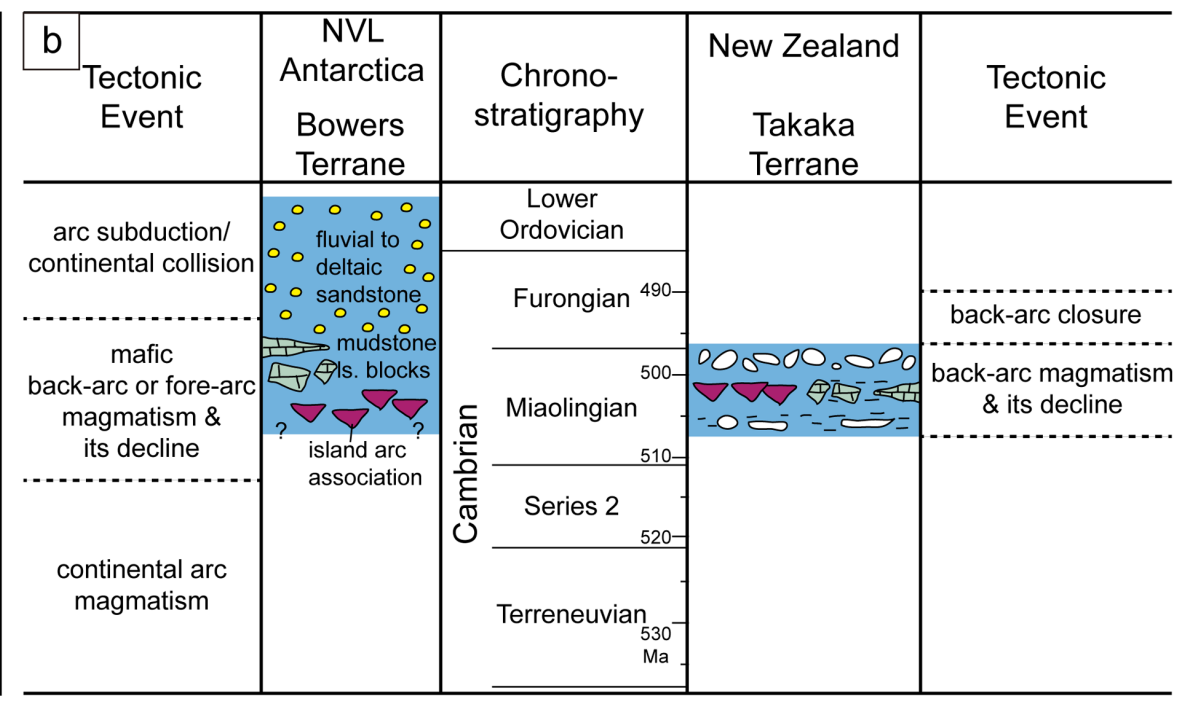

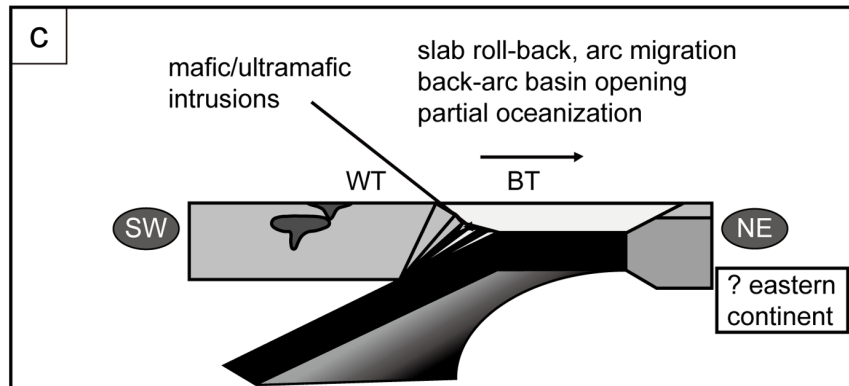

middle Miaolingian

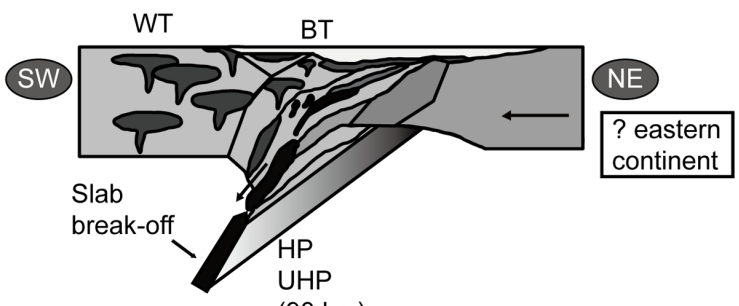

$(90 \mathrm{~km})$

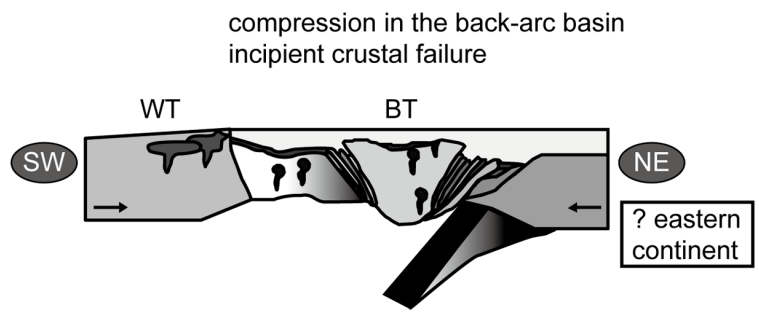

late Miaolingian

Furongian

Figure 10. (a) Paleogeographic map of eastern Gondwana during the early Paleozoic showing the close proximity of northern Victoria Land (NVL), southeastern Australia and New Zealand (NZ) in an orogenic belt. Modified from Cawood (2005). (b) Tectonic events and stratigraphy in the Bowers Terrane of northern Victoria Land, Antarctica and the Takaka Terrane in New Zealand. Note that the Miaolingian volcanics and shale-dominated successions containing limestone-bearing conglomerates were formed in both regions, when arc-related magmatism and its decline have taken place. (c) A geodynamic model for the Ross Orogeny in the NVL. Modified after Kleinschmidt and Tessensohn (1987), Münker and Cooper (1999) and Federico et al. (2006). 
et al., 2006, 2009; Rossetti et al., 2011; Fig. 10). These are supported by the stratigraphic position of the group and existence of a coesitebearing eclogite ( $498 \mathrm{Ma})$ in western margin of the Bowers Terrane (Federico et al., 2009; Rossetti et al., 2011; Kim et al., 2019). The upper Furongian to Lower Ordovician Leap Year Group consists mostly of continental facies which was envisaged as a result of deposition in the tectonic inversion of the basin, caused by possible continental collision and rapid exhumation reflected by occurrence of the retrogressed amphibolite facies (490 to $486 \mathrm{Ma}$ ) (Di Vincenzo et al., 1997; Federico et al., 2006, 2009; Rocchi et al., 2011; Rossetti et al., 2011). It is widely accepted that the extensional basin formation and regional uplift, triggered by the cratonward subduction, affected the shift from volcaniclastic-, deep-sea turbidite-, shallow-marine-, to non-marine-dominated sedimentation in this region (Rocchi et al., 2011; Fig. 10).

In this geodynamic context, some lines of integrated geochemical, petrological, and geochronologic evidences have delineated the nature of the shelf, which influenced the development of the Spurs Formation and the related sedimentary systems. Federico et al. (2006) proposed that the compressed Bowers back-arc basin can be subdivided into fault-bounded uplifted highs and associated basins, inferred by the extant Bowers Supergroup preserved from the partial subduction (Fig. 10c). Similarly, Rocchi et al. (2011) suggested development of several back-arc basins in between boudinaged continental fore-arcs, through evidences of partial oceanization in the Bowers back-arc (Ferraccioli et al., 2002). Presence of continent-derived granitoid clasts in conglomerate of the Sledgers (the Molar Formation) and Mariner (the Carryer Conglomerate) groups was ascribed to close proximity of the depositional area to the continental basement, which accommodated the eroded products transported relatively short distance (Federico et al., 2006). These inferences all support the situation of the uplifted shelf reconstructed by this work, where hinterland-derived siliciclastic influx was trapped in a shallow shelf on top of the antecedent topographic highs. The influx poisoned and inhibited carbonate production on the shallow shelf. Limited siliciclastic input and relative high-energy condition in the shelf margin, on the other hand, facilitated copious deposition of calcareous sediment. This optimal setting for carbonate production, established around the end of the back-arc extension, resulted in the development of probably short-lived, small carbonate platforms, until complete shutdown of carbonate production and eventual deposition of the siliciclastic Eureka Formation, both of which were triggered by a continued compression and regression. Such a scenario of the current work suggests that the initiation, development, and demise of the vanished carbonate platforms were mainly controlled by geodynamic evolution in the northern Victoria Land during the Ross Orogen.

\section{Significance of the Lost Carbonate Platforms Reconstructed from the Spurs Formation}

The majority of lower Paleozoic carbonate platforms were situated along tropical passive margins and intracratonic basins, which were generally bordered by inner detrital and outer fine-grained siliciclastic belts (Pratt et al., 2012; Labaj and Pratt, 2016). These platforms in the middle of shelf areas are the locus of carbonate production, where microbial, skeletal and non-skeletal calcareous sediment accumulated in a vast extent of shallow marine and are re-distributed by phys- icochemical and biologic factors (Schlager, 2005). Associated environments include tidal flats platform interior or lagoon, platform margin shoal adjacent to reefs, and deeper subtidal settings (e.g., Bova and Read, 1987; Saltzman, 1999; Pratt et al., 2012). Lime mud accumulated in many of these low-energy environments in lower Paleozoic systems. These carbonate platforms in the tectonically inactive settings broadly fit the widely used carbonate platform models (Schlager, 2005). On the other hand, different styles of carbonate platforms in terms of facies, size of the platform and tectonic setting also developed during the early Paleozoic. The Lower Ordovician La Silla Formation of the Argentine Precordillera is dominated by grainy lithofacies (Pratt et al., 2012), and this sedimentation was attributed to a combination of climate, environmental, ecological and tectonic controls. The interplay of these controls may have resulted in enhanced wave agitation, forming extensive peloidal sand flats in a passive margin (Pratt et al., 2012). Coeval carbonate platforms in active margin also reported from the Miaolingian Nelson Limestone in TAM near Weddell Sea of Antarctica (Evans et al., 2018), and the Upper Ordovician Lourdes Formation in eastern Canada (Hender and Dix, 2008). The former was deposited in fore-arc basin during a period of tectonic quiescence and resemble passive margin carbonate characteristics in facies, environments and depositional settings. The latter of a mixed carbonate-siliciclastic succession was deposited in the Taconic foreland basin in which narrow carbonate ramps, dominated by grainy sediment, developed during a short span of time when siliciclastic sediment of a transgressive systems tract was trapped in landward areas.

In contrast to a few styles of lower Paleozoic carbonate platforms, Cenozoic examples show a wide spectrum of the platform types, which developed in a range of tectonic settings, such as passive margins, intracratonic basins to failed rifts, and back-arc to foreland basins (Wilson, 2002; Bosence, 2005; Wilson and Hall, 2010). Specifically, syntectonic carbonate platforms, developed extensively in Southeast Asia, vary in size, facies and location, and the diverse styles occur in all of these tectonic settings (Wilson, 2002; Bosence, 2005; Wilson and Hall, 2010). This diverse nature of the Southeast Asian platforms has been considered to be resulted from direct influence of tectonics as well as indirect of climate, oceanography and type of carbonate producers (Wilson, 2002; Dorobek, 2008; Wilson and Hall, 2010). A comprehensive review of Wilson (2002) broadly categorized the platform characteristics into land-attached shelves, isolated platforms, and localized and ephemeral carbonates, which are characterized by extensive, mixed carbonate-clastic shelves, large-scale (tens of kilometers across) platforms on faulted highs and minor carbonate on faulted highs or isolated knoll/pinnacle reefs, respectively. The demise of these platforms is thought to mainly be influenced by tectonic subsidence, whereas smothering by siliciclastic or volcaniclastic influx, as a result of uplift and volcanism, is also known (Webster et al., 2004; Bosence, 2005; Wilson and Hall, 2010).

The missing carbonate platforms reconstructed in the current study appear to have markedly differed from coeval carbonate platforms of passive margin in size, lime mud production and tectonic setting. As discussed above, the close link of sedimentary patterns in the Mariner Group with geodynamic change in northern Victoria Land suggests that initiation, development, and demise of the vanished platform were likely influenced by orogenesis, specifically compression and uplift of the Bowers back-arc basin. Our findings demonstrate that small-sized 
carbonate platforms on top of the antecedent highs developed under somewhat harsh conditions, specifically a tectonically active setting, and that these were dominated by grainy sediment and reefs. Although similar platform characteristics among the lower Paleozoic examples were only reported from the Lourdes Formation in a foreland basin (Hender and Dix, 2008), numerous small-scale Cenozoic carbonate platforms assignable to the minor carbonate on faulted highs of Wilson (2002) were documented, in that fault-bounded highs accommodated rectilinear-, trapezoidal- and polygonal-shaped carbonate platforms in rift, passive margin, fore-arc, back-arc, and strike-slip basins (Bosence, 2005 and references therein). Of them, grainy deposits, which developed in mixed carbonate-siliciclastic shelf and shelf margin environments of back-arc setting, are recorded in various formations of Indonesia, which are comparable with the Spurs Formation in facies and geodynamic setting (Wilson, 2002). These platform carbonate deposits occurred in a time of transgressive and highstand systems tracts, when siliciclastic influxes were subdued in the carbonate environments (Wilson, 2002; Bosence, 2005; Dorobek, 2008; Hender and Dix, 2008). Although third-order depositional trends of the Spurs Formation have not been identified yet, such a style of carbonate platform in extent, facies, and tectonic setting may have not been unusual.

Northern Victoria Land of Antarctica was a juncture with southern New Zealand during the early Paleozoic, based in part on the fact that the Bowers Terrane of northern Victoria Land is comparable with the Takaka Terrane of New Zealand in terms of its lower Paleozoic stratigraphy and tectonic history (Federico et al., 2009; Fig. 10a, b). In the Takaka Terrane, back-arc magmatism took place in the Miaolingian and the resulting succession includes shale, volcanics and limestone olistoliths (Münker and Cooper, 1999; Federico et al., 2009; Fig. 10b). The results of this study, which tie in with geodynamic evolution, warrants further investigations on relicts of the carbonate platforms along the pacific margin of Gondwana in order to understand development of syn-orogenic, lower Paleozoic carbonate in active margin sedimentary basins.

\section{Conclusions}

Vanished carbonate platforms are deduced based on the character of the Miaolingian (middle Cambrian) slope deposits within the Spurs Formation in northern Victoria Land of Antarctica, a succession that accumulated during the opening and closing of a back-arc basin. The Spurs Formation consists largely of shale, sandstone and conglomerate facies, and lime mudstone is rare. Conglomerate facies includes disorganized limestone clasts ranging from granules to outsized boulders, with oolitic and muddy matrix. The majority of the limestone clasts are peloidal-oolitic packstone to grainstone and microbialites, whereas lime mudstone to wackestone is rare. Fabric and composition of the conglomerate indicate that these are debris flow deposits, derived largely from shallower carbonate shoals and microbial reefs. Limited occurrence of micritic limestone and relatively abundant sandstone interbeds in the Spurs Formation and thick shale and sandstone beds in the overlying Eureka Formation suggest large influx of siliciclastic sediment which may have interrupted the carbonate factory on the broad shelf during compressional stage of the back-arc basin. This resulted in the formation of narrow carbonate platforms along the shelf margin where negative effects of siliciclastic influx on the carbonate production were minimal. Such platform style is distinctive relative to that of coeval carbonate platforms with copious subtidal lime mud, ramp-like geomorphology and basin types such as passive margin and intracratonic basins. These findings reveal hidden carbonate sedimentation styles in the paleo-Pacific margin of Gondwana, which would be contrasted with styles of lower Paleozoic carbonate platforms in passive margin.

\section{Acknowledgements}

This study was supported by 2019 Research Grant from Kangwon National University and the National Research Foundation of Korea (NRF) grant funded by the Korea government (MSIT) to JH (No. 2020R1C1C1007690) and to JW (No. 2019R1A6A1A10073437), by Basic Science Research Program through the NRF funded by the Ministry of Education to JH and HKL (2019R1A6A1A03033167), and grant from Seoul National University to JW (New Faculty Startup Fund). The fieldwork on which this study based is a part of a KOPRI project (PE20200, KOPRI). We deeply appreciate the thorough and critical comments of P. Myrow, an anonymous reviewer, and the associate editor B. Pratt to improve the manuscript. We thank Dr. Changhwan Oh and Mr. Myeongho Seo for their support in the field camp in Antarctica and Messrs. Eun-Hyun Cho and Dae Chul Kim for figure preparation. Logistic supports from the Jang Bogo Station and pilots of HNZ are gratefully acknowledged.

\section{References}

Álvaro, J.J., Vennin, E., Moreno-Eiris, E., Perejón, A., and Bechstädt, T., 2000, Sedimentary patterns across the Lower-Middle Cambrian transition in the Esla nappe (Cantabrian Mountains, northern Spain). Sedimentary Geology, v. 137, pp. 43-61.

Andrews, P.B., and Laird, M.G., 1976, Sedimentology of a Late Cambrian regressive sequence (Bowers Group), northern Victoria Land, Antarctica. Sedimentary Geology, v. 16, pp. 21-44.

Arnott, R.W.C., 2010, Deep-marine sediments and sedimentary systems. In: James, N.P., and Dalymple, R.W. (Eds.), Facies Models 4. Geological Association of Canada, St. John's, pp. 295-322.

Bosence, D., 2005, A genetic classification of carbonate platforms based on their basinal and tectonic settings in the Cenozoic. Sedimentary Geology, v. 175, pp. 49-72.

Bova, J.A., and Read, J.F., 1987, Incipiently drowned facies within a cyclic peritidal ramp sequence, Early Ordovician Chepultepec interval, Virginia Appalachians. Geological Society of America Bulletin, v. 98, pp. 714-727.

Capponi, G., Crispini, L., and Meccheri, M., 1999, Structural history and tectonic evolution of the boundary between the Wilson and Bowers terranes, Lanterman Range, northern Victoria Land, Antarctica. Tectonophysics, v. 312, pp. 249-266.

Cawood, P.A., 2005, Terra Australis Orogen: Rodinia breakup and development of the Pacific and Iapetus margins of Gondwana during the Neoproterozoic and Paleozoic. Earth-Science Reviews, v. 69, pp. 249 279.

Coniglio, M., and Dix, G.R., 1992, Carbonate slopes. In: Walker, R.G., and James, N.P. (Eds.), Facies Models: Response to Sea Level Change. Geological Association of Canada, St. John's, pp. 349-374.

Cooper, R.A., Jago, J.B., Rowell, A.J., and Braddock, P., 1983, Age and 
correlation of the Cambrian-Ordovician Bowers Supergroup, northern Victoria Land. In: Jago, J.B., Oliver, R.L., and James, P.R. (Eds.), Antarctic Earth Science. Cambridge, New York, Cambridge University Press, pp. 128-131.

Cooper, R.A., Begg, J.G., and Bradshaw, J.D., 1990, Cambrian trilobites from Reilly Ridge, northern Victoria Land, Antarctica, and their stratigraphic implications. New Zealand Journal of Geology and Geophysics, v. 33, pp. 55-66.

Cooper, R.A., Jago, J.B., and Begg, J.G., 1996, Cambrian trilobites from northern Victoria Land, Antarctica, and their stratigraphic implications. New Zealand Journal of Geology and Geophysics, v. 39, pp. 363-387.

Courjault-Rade, P., Debrenne, F., and Gandin, A., 1992, Palaeogeogrpahic and geodynamic evolution of the Gondwana continental margins during the Cambrian. Terra Nova, v. 4, pp. 657-667.

Demicco, R.V., 1985, Platform and off-platform carbonates of the Upper Cambrian of western Maryland, U.S.A. Sedimentology, v. 32, pp. 1-22.

Di Vincenzo, G., Palmeri, R., Talarico, F., Andriessen, P.A.M., Ricci, C.A., 1997, Petrology and geochronology of eclogites from the Lanterman Range, Antarctica. Journal of Petrology, v. 38, pp. 1391-1417.

Di Vincenzo, G., Ghiribelli, B., Giorgetti, G., and Palmeri, R., 2001, Evidence of a close link between petrology and isotope records; constraints from SEM, EMP, TEM and in situ ${ }^{40} \mathrm{Ar} /{ }^{\beta 9} \mathrm{Ar}$ laser analyses on multiple generations of white micas (Lanterman Range, Antarctica). Earth Planetary Science Letters, v. 192, pp. 389-405.

Dorobek, S.L., 2008, Carbonate-platform facies in volcanic-arc settings: Characteristics and controls on deposition and stratigraphic development. GSA Special Paper, v. 436, pp. 55-90.

Drzewiecki, P.A., and Sim, J.A., 2002, Depositional processes, triggering mechanisms and sediment composition of carbonate gravity flow deposits: examples from the Late Cretaceous of the south-central Pyrenees, Spain. Sedimentary Geology, v. 146, pp. 155-189.

Evans, K.R., McKenna III, L.W., Lieberman, B.S., Weichert, W.D., and Macleod, K.G., 2018, Geology of the Nelson Limestone, Postel Nunatak, Patuxent Range, Antarctica. Antarctic Science, v. 30, pp. 29-43.

Federico, L., Capponi, G., and Crispini, L., 2006, The Ross Orogeny of the Transantarctic Mountains: a northern Victoria Land perspective. International Journal of Earth Sciences, v. 95, pp. 759-770.

Federico, L., Crispini, L., Capponi, G., and Bradshaw, J., 2009, The Cambrian Ross Orogeny in northern Victoria Land (Antarctica) and New Zealand: a synthesis. Gondwana Research, v. 15, pp. 188-196.

Ferraccioli, F., Bozzo, E., Capponi, G., 2002, Aeromagnetic and gravity anomaly constraints for an early Paleozoic subduction system of Victoria Land, Antarctica. Geophysical Research Letters, v. 29. doi:10.1029/ 20012001 GLO20014138

Flügel, E., 2010, Microfacies of carbonate rocks. Springer-Verlag, Berlin Heidelberg, $984 \mathrm{p}$.

Flügel, E., and Koch, R., 1995, Controls on the diagenesis of Upper Triassic carbonate ramp sediments: Steinplatte, northern Alps (Austria). Geologisch-Paläeontologische Mitteilungen Innsbruck, v. 20, pp. 283311.

Foster, D.A., Gray, D.R., and Spaggiari, C., 2005, Timing of subduction and exhumation along the Cambrian Gondwana margin, and the formation of Paleozoic backarc basins. Geological Society of America Bulletin, v. 117, pp. 105-116.

Geyer, G., and Shergold, J., 2000, The quest for internationally recognized divisions of Cambrian time. Episodes, v. 23, pp. 188-195.

Glumac, B., and Walker, K.R., 1997, Selective dolomitization of Cambrian microbial carbonate deposits: A key to mechanisms and environments of origin. Palaios, v. 12, pp. 98-110.

Goldhammer, R.K., Lehmann, P.J., and Dunn, P.A., 1993, The origin of highfrequency platform carbonate cycles and third-order sequences (Lower Ordovician El Paso Gp, West Texas): Constraints from outcrop data and stratigraphic modeling. Journal of Sedimentary Petrology, v. 63, pp. 318-359.

Gomez, F.J., and Astini, R.A., 2015, Sedimentology and sequence stratig- raphy from a mixed (carbonate-siliciclastic) rift to passive margin transition: The Early to Middle Cambrian of the Argentine Precordillera. Sedimentary Geology, v. 316, pp. 39-61.

Haughton, P., Davis, C., McCaffrey, W., and Barker, S., 2009, Hybrid sediment gravity flow deposits-classification, origin and significance. Marine and Petroleum Geology, v. 26, pp. 1900-1918.

Hender, K.L.B., and Dix, G.R., 2008, Facies development of a Late Ordovician mixed carbonate-siliciclastic ramp proximal to the developing Taconic orogeny: Lourdes Formation, Newfoundland, Canada. Facies, v. 54, pp. 121-149.

James, N.P., 1981, Megablocks of calcified algae in the Cow Head Breccia, western Newfoundland: Vestiges of a Cambro-Ordovician platform margin. Geological Society of America Bulletin, v. 92, pp. 799-811.

James, N.P., and Gravestock, D.I., 1990, Lower Cambrian shelf and shelf margin buildups, Flinders Ranges, South Australia. Sedimentology, v. 37, pp. 55-480.

Kim, Y.H., Woo, J., Park, T.-Y.S., Kihm, J.-H., Lee, J.I., and Choe, M.Y., 2018, Cyclic deposit of breccia and diamictite in the Spurs Formation, the Mariner Group (Cambrian), northern Victoria Land, Antarctica: two kinds of debris flows in a submarine channel system. Antarctic Science, v. 30, pp. 245-263.

Kim, T., Kim, Y., Cho, M., and Lee, J.I., 2019, P-T evolution and episodic zircon growth in barroisite eclogites of the Lanterman Range, northern Victoria Land, Antarctica. Journal of Metamorphic Geology, v. 37, pp. 509-537.

Kleinschmidt, G., and Tessensohn, F., 1987, Early Paleozoic westward directed subduction at the Pacific margin of Antarctica. In: McKenzie, GD. (Ed.), Gondwana Six: Structure, Tectonics, and Geophysics. American Geophysical Union Geophysical Monograph Washington DC, 40, pp. 89-105.

Kneller, B., and Buckee, C., 2000, The structure and fluid mechanics of turbidity currents: a review of some recent studies and their geological implications. Sedimentology, v. 47, pp. 62-94.

Kwon, Y.K., and Chough, S.K., 2005, Sequence stratigraphy of the cyclic successions in the Dumugol Formation (Lower Ordovician), Mideast Korea. Geosciences Journal, v. 9, pp. 305-324.

Kwon, Y.K., Chough, S.K., Choi, D.K., and Lee, D.J., 2006, Sequence stratigraphy of the Taebaek Group (Cambrian-Ordovician), Mideast Korea. Sedimentary Geology, v. 192, pp. 19-55.

Labaj, M.A., and Pratt, B.R., 2016, Depositional dynamics in a mixed carbonate-siliciclastic system: middle-upper Cambrian Abrigo Formation, southeastern Arizona, U.S.A. Journal of Sedimentary Research, v. 86, pp. 11-37.

Laird, M.G., and Bradshaw, J.D., 1983, New data on the lower Paleozoic Bowers Supergroup, northern Victoria Land. In Jago, J.B., Oliver, R.L., and James, P.R. (Eds.), Antarctic Earth Science. Cambridge University Press, Cambridge, New York, pp. 123-126.

Läufer, A.L., Lisker, F., and Phillips, G., 2011, Late Ross-orogenic deformation of basement rocks in the northern Deep Freeze Range, Victoria Land, Antarctica: the Lichen Hills Sear Zone. Polarforschung, v. 80, pp. 60-70.

Lee, J.-H., Chen, J., and Chough, S.K., 2015, The Middle-Late Cambrian reef transition and related geological event: A review and new view. Earth-Science Reviews, v. 145, pp. 66-84.

Maltman, A.J., and Bolton, A., 2003, How sediments become mobilized. In: Van Rensbergen, P., Hillis, R.R., Maltman, A.J., and Morley, C.K. (Eds.), Subsurface sediment mobilization. Geological Society of London, Special Publication, 216, pp. 9-20.

Markello, J.R., and Read, J.F., 1981, Carbonate ramp-to-deeper shale shelf transitions of an Upper Cambrian intrashelf basin, Nolichucky Formation, southwest Virginia Appalachians. Sedimentology, v. 28, pp. 573597.

Myrow, P.M., Pope, M.C., Goodge, J.W., Fischer, W., and Palmer, A.R., 2002, Depositional history of pre-Devonian strata and timing of Ross orogenic tectonism in the central Transantarctic Mountains, Antarc- 
tica. Geological Society of America Bulletin, v. 114, pp. 1070-1088.

Myrow, P.M., Snell, K.E., Hughes, N.C., Paulsen, T.S., Heim, N.A., and Parcha, S.K., 2006, Cambrian depositional history of the Zanskar Valley region of the Indian Himalaya: Tectonic implications. Journal of Sedimentary Research, v. 76, pp. 364-381.

Mulder, T., and Alexander, J., 2001, The physical character of subaqueous sedimentary density flows and their deposits. Sedimentology, v. 48, pp. 269-299.

Münker, C., and Cooper, R., 1999, The Cambrian arc complex of the Takaka Terrane, New Zealand: an integrated stratigraphical, paleontological and geochemical approach. New Zealand Journal of Geology and Geophysics, v. 42, pp. 415-445.

Osleger, D.A., and Montañez, I.P., 1996, Cross-platform architecture of a sequence boundary in mixed siliciclastic-carbonate lithofacies, Middle Cambrian, southern Great Basin, USA. Sedimentology, v. 43, pp. 197-217.

Owen, G., and Moretti, M., 2011, Identifying triggers for liquefactioninduced soft-sediment deformation in sands, Sedimentary Geology, v. 235, pp. 141-147.

Park, T.-Y.S, Kihm, J.-H., Woo, J., Kim, Y.-H.G., and Lee, J.-I., 2016, Ontogeny of the Furongian (Late Cambrian) trilobite Proceratopyge cf. P. Lata Whitehouse from northern Victoria Land, Antarctica and the evolution of metamorphosis in trilobites. Palaeontology, v. 59, pp. 657-670.

Paulsen, T.S., Deering, C., Slinwinski, J., Bachmann, O., and Guillong, M., 2016, Detrital zircon ages from the Ross Supergroup, north Victoria Land, Antarctica: Implications for the tectonostratigraphic evolution of the Pacific-Gondwana margin. Gondwana Research, v. 35, pp. 79-96.

Pfeil, R.W., and Read, J.F. 1980, Cambrian carbonate platform margin facies, Shady Dolomite, southwestern Virginia, U.S.A. Journal of Sedimentary Petrology, v. 50, pp. 91-116.

Pillevuit, A., Marcoux, J., Stampfli, G., and Baud, A., 1997, The Oman exotics: a key to the understanding of the Neotethyan geodynamic evolution. Geodinamica Acta, v. 10, pp. 209-238.

Playton, T.E., Janson, X., and Kerans, C., 2010, Carbonate slopes. In James, N.P. and Dalymple R.W. (Eds.), Facies Models 4. Geological Association of Canada, St. John's, pp. 449-476.

Pohler, S.M.L., and James, N.P., 1989, Reconstruction of a Lower/Middle Ordovician shelf margin: Cow Head Group, Western Newfoundland. Facies, v. 21, pp. 189-262.

Pratt, B.R., and James, N.P., 1986, The St George Group (Lower Ordovician) of western Newfoundland: tidal flat island model for carbonate sedimentation in shallow epeiric seas. Sedimentology, v. 33, pp. 313343.

Pratt, B.R., Raviolo, M.M., and Bordonaro, O.L., 2012, Carbonate platform dominated by peloidal sands: Lower Ordovician La Silla Formation of the eastern Precordillera, San Juan, Argentina. Sedimentology, v. 59, pp. 843-866.

Read, J.F., and Pfeil, R.W., 1983, Fabrics of allochthonous reefal blocks, Shady Dolomite (Lower to Middle Cambrian), Virginia Appalachians. Journal of Sedimentary Petrology, v. 53, pp. 761-778.

Rees, M.N., 1986, A fault-controlled trough through a carbonate platform: The Middle Cambrian House Range embayment. Geological Society of America Bulletin, v. 97, pp. 1054-1069.

Rees, M.N., Pratt, B.R., and Rowell, A.J., 1989, Early Cambrian reefs, reef complexes, and associated lithofacies of the Shackleton Limestone, Transantarctic Mountains. Sedimentology, v. 36, pp. 341-361.

Riding, R., 2000, Microbial carbonates: the geological record of calcified bacterial-algal mates and biofilms. Sedimentology, v. 47, pp. 179-214.

Rocchi, S., Bracciali, L., Di Vincenzo, G., Gemelli, M., and Ghezzo, C., 2011, Arc accretion to the early Paleozoic Antarctic margin of Gondwana in Victoria Land. Gondwana Research, v. 19, pp. 594-607.
Rossetti, F., Vignaroli, G., Di Vincenzo, G., Gerdes, A., Ghezzo, C., Theye, T., and Balsamo, F., 2011, Long-lived orogenic construction along the paleo-Pacific margin of Gondwana (Deep Freeze Range, North Victoria Land, Antarctica). Tectonics, v. 30, TC4008, doi:10.1029/2010TC002804

Rowland, S.M., and Shapiro, R.S., 2002, Reef patterns and environmental influences in the Cambrian and earliest Ordovician. In Kiessling, W., Flgel, E., and Golonka, J. (Eds.), Phanerozoic Reef Patterns. SEPM Special Publication 72, Tulsa, pp. 95-128.

Saltzman, M.R., 1999, Upper Cambrian carbonate platform evolution, Levinia and Taenicephalus zones (pterocephaliid-ptychaspid Biomere boundary), northwestern Wyoming. Journal of Sedimentary Research, v. 69, pp. 926-938.

Schlager, W., 2005. Carbonate Sedimentology and Sequence Stratigraphy. SEPM, Tulsa, $200 \mathrm{p}$.

Sim, M.S., and Lee, Y.I., 2006, Sequence stratigraphy of the Middle Cambrian Daegi Formation (Korea), and its bearing on the regional stratigraphic correlation. Sedimentary Geology, v. 191, pp. 151-169.

Sohn, Y.K., Choe, M., and Jo, H., 2002, Transition from debris flow to hyperconcentrated flow in a submarine channel (the Cretaceous Cerro Toro Formation, southern Chile). Terra Nova, v. 14, pp. 405-415.

Soja, C.M., 1996, Island-arc carbonates: characterization and recognition in the ancient geologic record. Earth-Science Reviews, v. 41, pp. 31-65.

Srinivasan, K., and Walker, K.R., 1993, Sequence stratigraphy of an intrashelf basin carbonate ramp to rimmed platform transition: Maryville Limestone (Middle Cambrian), southern Appalachians. Geological Society of America Bulletin, v. 105, pp. 883-896.

Steiger, T., 1981, Kalkturbidite im Oberjura der Nördlichen Kalkalpen (Barmsteinkalke, Salzburg, Österreich). Facies, v. 4, pp. 215-348.

Stevenson, C.J., Talling, P.J., Masson, D.G., Sumner, E.J., Frenz, M., and Wynn, R.B., 2014, The spatial and temporal distribution of grain-size breaks in turbidites. Sedimentology, v. 61, pp.1120-1156.

Talling, P.J., Masson, D.G., Sumner, E.J., and Malgesini, G., 2012, Subaqueous sediment density flows: depositional processes and deposit types. Sedimentology, v. 59, pp. 1937-2003.

Watts, K.F., and Garrison, R.E., 1986, Sumeini Group, Oman-Evolution of a Mesozoic carbonate slope on a south Tethyan continental margin. Sedimentary Geology, v. 48, pp. 107-168.

Webby, B.D., 2002, Patterns of Ordovician reef development. In Kiessling, W., Flgel, E., and Golonka, J., (Eds.), Phanerozoic Reef Patterns. SEPM Special Publication 72, Tulsa, pp. 129-180.

Webster, J.M., Wallace, L., Silver, E., Potts, D., Braga, J.C., Renema, W., Riker-Coleman, K., and Gallup, C., 2004, Coralgal composition of drowned carbonate platforms in the Huon Gulf, Papua New Guinea; implications for lowstand reef development and drowning. Marine Geology, v. 204, pp. 59-89.

Wilson, M.E.J., 2002, Cenozoic carbonates in Southeast Asia: implications for equatorial carbonate development. Sedimentary Geology, v. 147, pp. 295-428.

Wilson, M.E.J., and Bosence, D.W.J., 1996, The Tertiary evolution of South Sulawesi: a record in redeposited carbonates of the Tonasa Limestone Formation. In Hall, R., and Blundell, D.J., (Eds.), Tectonic Evolution of SE Asia. Geological Society of London, Special Publication, 106, pp. 365-389.

Wilson, M.E.J., and Hall, R., 2010, Tectonic influences on SE Asian carbonate systems and their reservoir development. In Morgan, W.A., George, A.D., Harris, P.M., Kupecz, J.A., and Sarg, J.F., (Eds.), Cenozoic Carbonate Systems of Australasia. SEPM Special Publication 95, Tulsa, pp. 13-40.

Youngs, B.C., 1978, The petrology and depositional environments of the Middle Cambrian Wirrealpa and Aroona Creek limestones (South Australia). Journal of sedimentary Petrology, v. 48, pp. 63-74. 


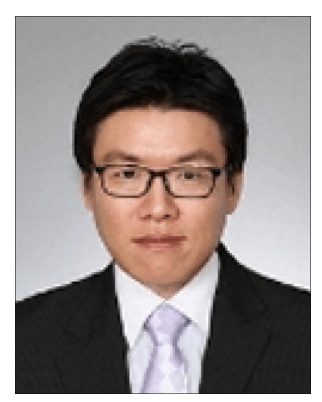

Jongsun Hong is an assistant professor in the Department of Geology at Kangwon National University, Korea. He received his Ph.D. from Korea University and was awarded the young geologist from the Geological Society of Korea. His research interests are centered around carbonate sedimentology, highfrequency sequence stratigraphy and paleoecology. Currently he focuses on evolutionary patterns of lower Paleozoic carbonate facies and reefs in Northeast Asia and Antarctica.

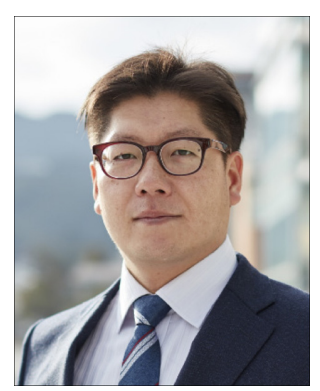

Jusun Woo is an assistant professor of sedimentary geology in the School of Earth and Environmental Sciences, Seoul National University, Korea. He received his Ph.D. from Seoul National University, Korea. He worked for Korea Polar Research Institute, exploring Antarctic and Arctic sedimentary basins, for 9 years. His research interests include sedimentology and sequence stratigraphy of siliciclastic and carbonate successions in eastern Gondwana.

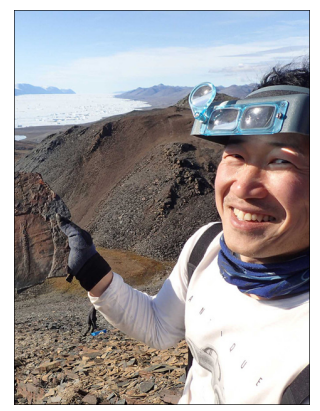

Tae-Yoon S. Park is a senior research scientist at Korea Polar Research Institute. His interests include early evolution of invertebrates and Cambrian biostratigraphy. His current research is on the palaeobiology of fossils of the Sirius Passet biota from North Greenland. He is serving as a voting member of the International Subcommission on Cambrian Stratigraphy.

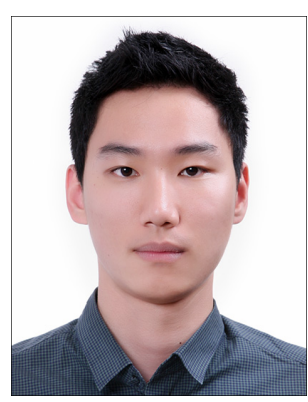

Ji-Hoon Kihm is a Ph.D. candidate at Korea Polar Research Institute and University of Science \& Technology, Korea. He is interested in evolution of Cambrian metazoans and extant tardigrades. His current research focuses on systematics of polar tardigrades and the morphological comparison between tardigrades and Cambrian lobopodians.

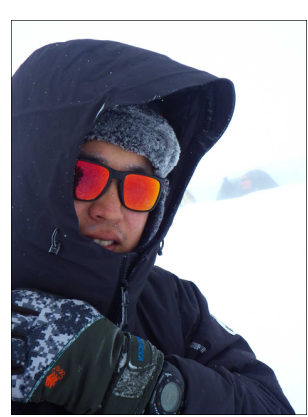

Young-Hwan G Kim is a Ph.D. candidate at University of Science \& Technology, Korea. $\mathrm{He}$ is interested in Paleozoic depositional history of the basins in Gondwana. He has been working on the Cambrian stratigraphy and depositional processes of a back-arc basin in the Bowers Terrane, northern Victoria Land, Antarctica.

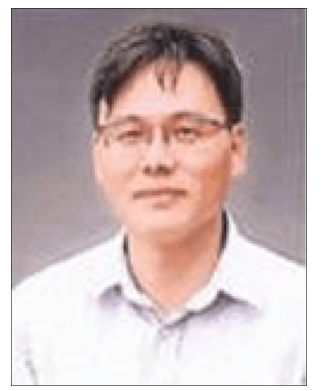

Hee-Kwon Lee is a professor in the Department of Geology at Kangwon National University, Korea. He received his Ph.D. from McMaster University, Canada. His research interest is ESR dating of active fault systems, and structural analysis of fault-bounded basin. 